\title{
PATAGONIA EN LA EDAD DE ORO DE LA CARTOGRAFÍA HOLANDESA: UNA GENEALOGÍA DEL GIGANTUM REGIO (S. XVII)
}

CAROLINA MARTÍNEZª

\section{RESUMEN}

El presente artículo examina el proceso de consolidación del área magallánico-fueguina como tierra de gigantes en el contexto de expansión transoceánica europea de los siglos XVI y XVII. Para ello, reconstruye las diferentes instancias de producción y circulación en las que, en términos cartográficos, se afianzó el mito de los gigantes patagónicos. En el transcurso de los siglos XVI y XVII la presencia de hombres de gran tamaño, descripta por Antonio Pigafetta hacia 1524, se convirtió en un topos recurrente en los relatos de viaje a la América meridional, siendo su supuesta existencia objeto de debate hasta finalizado el siglo XVIII. En este proceso, la cartografía holandesa del siglo XVII tuvo un papel determinante pues, en diálogo con el texto impreso, terminó por dotar de una identidad específica a aquella remota área geográfica. Con el objetivo de comprender las variables políticas y culturales que incidieron en el desarrollo de una cartografía específica sobre el Gigantum Regio, los mapas sobre el estrecho de Magallanes producidos en la edad de oro de la cartografía holandesa son analizados en relación con la cartografía ibérica precedente, así como con los relatos de viaje producidos en el marco de las rivalidades de las distintas potencias ultramarinas entre fines del siglo XVI y comienzos del siglo siguiente.

PALABRAS CLAVE: Patagonia, Gigantum Regio, cartografía holandesa, siglo XVII, estrecho de Magallanes.

\section{PATAGONIA IN THE GOLDEN AGE OF DUTCH CARTOGRAPHY: A GENEALOGY OF THE GIGANTUM REGIO $\left(17^{\text {th }} \mathrm{C}\right.$.)}

\footnotetext{
ABSTRACT

This paper examines the process by which the Magellanic-Fuegian area consolidated as a land of giants in the context of European transoceanic expansion in the $16^{\text {th }}$ and $17^{\text {th }}$ centuries. In order to do so, it reconstructs the different contexts of production and circulation in which, cartographically speaking, the myth of the Patagonian giants was strengthened. In the course of

a Consejo Nacional de Investigaciones Científicas y Técnicas (CONICET)/Universidad Nacional de San Martín (LICH-UNSAM)Universidad de Buenos Aires (UBA). Cap. Gral. Ramón Freire 2182, 2 17, Ciudad de Buenos Aires (1428).

$\ltimes$ cmartinez79@gmail.com
} 
the $16^{\text {th }}$ and $17^{\text {th }}$ centuries the presence of large men, as described by Antonio Pigafetta around 1524 , became a recurring topic in the travel accounts to South America, their alleged existence being debated until the end of the $18^{\text {th }}$ century. In this process, in dialogue with the printed text, $17^{\text {th }}$ century Dutch cartography played a decisive role, as it ended up giving a specific identity to that remote geographical area. In order to understand the political and cultural variables that shaped the development of a specific cartography on the Gigantum Regio, the maps of the Strait of Magellan produced in the Golden Age of Dutch cartography are analyzed in relation to the previous Iberian cartography as well as with the travel accounts produced amidst the overseas rivalries developed between the end of the $16^{\text {th }}$ and the beginning of the $17^{\text {th }}$ centuries.

KEY WORDS: Patagonia, Gigantum Regio, Dutch Cartography, 17th Century, Strait of Magellan.

\section{PRIMERAS NOTICIAS EN EUROPA SOBRE EL ÁREA MAGALLÁNICO-FUEGUINA}

A partir del análisis de una serie de imágenes cartográficas sobre el área magallánico-fueguina producidas en el siglo de oro holandés ${ }^{1}$, el presente trabajo indaga en el proceso de construcción de un espacio cartográfico icónico tal como fue la "Región de los Gigantes" en el extremo sur de América meridional ${ }^{2}$. Para ello, busca reconstruir la compleja trama de relatos de viaje, grabados y mapas que, hacia mediados del siglo XVII, se consolidaron en una representación sintética e inequívoca de la región patagónica y sus habitantes ${ }^{3}$. Se propone que, desde el encuentro inaugural descripto por Antonio Pigafetta en el marco de la expedición MagallanesElcano (1519-1522), los relatos de viaje jugaron un papel vital en la provisión de nuevas informaciones (fidedignas o no) sobre los habitantes de la zona del

1 La edad de oro holandesa o siglo de oro holandés comprende el período que aproximadamente se extiende desde la fundación de la Compañía holandesa de Indias Orientales en 1602 hasta finales de ese siglo. Sobre el despegue y auge de las Provincias Unidas en términos económicos, políticos y culturales véase: Israel, 1997a. Conflicts of Empires: Spain, the Low Countries and the struggle for world supremacy, 1585-1713. The Hambledon Press, Londres; Israel, 1998. The Dutch Republic: Its Rise, Greatness and Fall, 1477-1806. Clarendon Press of Oxford University Press, Nueva York. Un análisis exhaustivo del desarrollo cartográfico holandés durante su edad de oro puede consultarse en: Schilder, 1986-2013. Monumenta Cartographica Neerlandica. Uitgeverij Canaletto, Alphen aan den Rijn, 9 Vols.

2 La expresión "espacio icónico" ha sido utilizada por Frank Lestringant en relación con la forma unívoca de representar a los patagones. Lestringant, 2003. Sous la leçon des vents. Le monde d'André Thevet, cosmographe de la Renaissance. Presses de l'Université Paris-Sorbonne, Paris, p. 289. estrecho de Magallanes. De hecho, la experiencia magallánica refrendó que la región próxima al pasaje interoceánico fuera designada Gigantum Regio o "Tierra de Gigantes", topónimo que no solamente reconoció Pedro Sarmiento de Gamboa hacia 1580, sino que también retomaron los cartógrafos y navegantes ajenos a los intereses de la monarquía hispánica ${ }^{4}$. Fue la cartografía holandesa, sin embargo, la que entre fines del siglo XVI y comienzos del siglo siguiente compuso y consolidó una determinada imagen del sur americano.

En efecto, los mapas impresos en los principales centros editoriales y cartográficos de las recientemente creadas Provincias Unidas de los Países Bajos ${ }^{5}$ refrendaron la presunción de que el Gigantum o Patagonum Regio era una tierra poblada por seres de gran tamaño: de $9 \&$ ad summum 10 pedes longi, según establecía Jan Huygen van Linschoten en el mapa que acompañó

3 La creación de un espacio cartográfico icónico para el área magallánico-fueguina se observa en los mapas de Pieter van den Keere (1614), Jodocus Hondius (1620), Nicolaes Visscher (1633), William Janszoon Blaeu (1635) y Frederik de Wit (1675), entre otros.

4 Martinic, 1971. Reseña del descubrimiento y de la evolución cartográfica de la región magallánica. Instituto de la Patagonia, Punta Arenas. En la primera carta sectorial del canal, realizada por Pedro Sarmiento de Gamboa, el navegante hace referencia a la bahía Gente Grande entre otros topónimos y accidentes geográficos.

5 Tal como las define Manuel Herrero Sánchez, las Provincias Unidas fueron una realidad estatal surgida con la firma de la Unión de Utrecht en 1579, incluyeron las siete provincias unidas de Holanda, Zelanda, Utrecht, Güeldres, Groninga, Overijssel y Frisia y se convirtieron en una república independiente en 1588 tras la retirada del duque de Leicester. Herrero, 1999. Las Provincias Unidas y la Monarquía Hispánica: (1588-1702). Cuadernos de Historia 72-Arco Libros, Madrid. 
a su Itinerario de $1596^{6}$, e incluso de 11 et ad summum 13 spit. hamas longi, tal como señalaba Michael Mercator, nieto del gran cartógrafo, en su mapa de América publicado un año antes ${ }^{7}$. Las informaciones utilizadas para la confección de piezas cartográficas como las aquí mencionadas fueron ciertamente variadas, contándose como valiosos insumos las noticias e imágenes que podían producirse tanto fuera como dentro del mundo del impreso. A su vez, su circulación y eventual llegada a manos y oídos de los cartógrafos holandeses estuvo sujeta a los vaivenes de la competencia transoceánica $y$, en el caso particular del Estrecho, a la importancia estratégica que las distintas potencias ultramarinas otorgaron al control del pasaje interoceánico.

En cuanto a la genealogía del Gigantum Regio, sus orígenes deben buscarse en los testimonios de la mencionada experiencia magallánica. La existencia de gigantes en las costas orientales de América meridional fue anunciada por primera vez en los escritos de Pigafetta, testigo del primer viaje de circunnavegación español realizado entre 1519 y 1522 bajo la dirección de Fernando de Magallanes $y$, tras su muerte, de Juan Sebastián Elcano. Al testimonio de Pigafetta debe sumarse la carta dirigida a Mateo Lang que Maximiliano Transilvano confeccionara en 1522 y la carta destinada al Papa Adriano VI que algunos años más tarde Pedro Mártir de Anglería publicó en la quinta década de su Orbe Novo $(1530)^{8}$. Dentro del conjunto de relatos

6 Linschoten publicó su mapa, titulado Delineatio ómnium orarum totius Australis partis Americae, Dictae Peruvianae, a $R$ de la Plata, Brasiliam..., y grabado en metal por Arnold Florent van Langren, junto a su Itinerario en Ámsterdam en 1596.

7 El America sive India nova ad magnae Gerardi Mercatoris aui universalis imitationem in compendium redacta. Per Michaelem Mercatorem Duysburgensem, incluido en el Atlas cosmographicae meditationes de fabrica mundi, fue publicado por Michael Mercator en Ámsterdam en 1595.

8 La carta a Adriano VI fue redactada por Pedro Mártir en España en 1522

9 El documento de Albo se encuentra en el Archivo General de Indias, Sevilla, Fondo Patronato, leg. 34, Ramo 5. El manuscrito de Mafra se encuentra en la Biblioteca Nacional de Madrid y posee 108 folios. En el marco de las celebraciones por los 500 años de la gesta magallánica, el conjunto de testimonios producto del viaje ha sido recientemente editado por Ediciones Miraguano-Polifemo.

10 Castro et al. (Eds.), 2007. Le voyage de Magellan (1519-1522). La relation d'Antonio Pigafetta \& autres témoignages. Prefacio de Carmen Bernand y Xavier de producidos en el marco de la expedición magallánica también se encuentran los testimonios de Francisco Albo, Ginés de Mafra, Gonzalo Gómez de Espinosa, León Pancaldo y las cartas de Antonio Brito y Juan Sebastián Elcano, que solo abandonaron su condición de manuscritos décadas (y aun siglos) más tarde y no necesariamente refirieron el hallazgo de poblaciones costeras en la bahía de San Julián, en la actual Patagonia argentina ${ }^{9}$. En este sentido, merecen especial atención los relatos de Pigafetta y Transilvano, cuyo éxito y circulación en incontables ediciones y formatos a lo largo de los siglos XVI y el XVII consolidaron una determinada mirada sobre los habitantes de la región.

En el caso de Pigafetta, tras circular de forma manuscrita en Roma y Vicenza entre 1523 y $1524^{10}$, su relato de viaje fue publicado por primera vez, en francés, en 1526. Bajo el título Le Voyage et navigation faict par les Espaignolz és Isles de Mollucques, des iles qu'ilz ont trouvé audict voyage, des roys d'icelles, de leur gouvernement et manière de vivre, avec plusieurs aultres choses..., la obra narraba, entre muchos otros incidentes y observaciones, el hallazgo de gigantes en el Puerto de San Julián ${ }^{11}$. Un día, de pronto, descubrimos a un hombre de gigantesca estatura, el cual, desnudo sobre la ribera del puerto, bailaba, cantaba y vertía polvo sobre su cabeza, describe Pigafetta, quien luego señala: Era tan alto él, que no le pasábamos de la cintura...

Castro, Chandeigne, París, p. 72.

11 Bajo el título completo de Le Voyage et navigation faict par les Espaignolz és Isles de Mollucques [Texte imprimé], des iles qu'ilz ont trouvé audict voyage, des roys d'icelles, de leur gouvernement et manière de vivre, avec plusieurs aultres choses..., la obra de Pigafetta fue publicada por Simon Colines en París en 1526. Esta versión se tradujo al italiano en 1536 y en Inglaterra hacia 1579. Si bien otros autores han considerado que la obra data de 1525, Lestringant sostiene que el verdadero año de publicación es 1526. Antes de esta edición, existieron varias versiones manuscritas. En principio, la versión original del relato, hoy perdida, se escribió en italiano entre 1523 y 1524 . Existen en la actualidad varias versiones manuscritas que sintetizan el diario de a bordo. De todas ellas, la más completa es la que posee la Universidad de Yale y que lleva por título: "Navigation et descouvrement de la Indie supérieure, et isles de Malucques, ou naissent les cloux de girofle, faicte par Anthoine Pigaphete Vincentin Chevallier de Rohdes, commenceant en l'an 1519", Beinecke Library, ms. 351, Yale University. Usher, 2014. 'Ils n'ont point de ville': l'urbanisation des espaces lointains a la Renaissance. Seizième Siècle, 10, 227-244, p. 231. 
En cuanto a las mujeres, el vicentino indica: ... no eran tan altas, pero sí mucho más gordas. Cuando las vimos de cerca, nos quedamos atónitos: tienen los pechos largos hasta la mitad del brazo. Seguidamente, el navegante narra una serie de incidentes entre la tripulación y los pobladores locales, bautizados patagones por el propio Magallanes y considerados gigantes por su enorme estatura ${ }^{12}$.

Por su parte, en 1522 Maximiliano Transilvano, secretario de Carlos V, redactó una carta a Mateo Lang de Wellenburg, cardenal arzobispo de Salzburgo y obispo de Cartagena, en la que se detallaban los logros de la expedición MagallanesElcano $^{13}$. En dicho escrito, impreso el año siguiente y difundido en numerosas ediciones, Transilvano (que no fue parte de la expedición) defendía la veracidad de lo narrado anclándose en el testimonio fidedigno del capitán (Elcano) y de los marinos, quienes tras su regreso a Sevilla en octubre de 1522 se habían entrevistado con el Secretario Real ${ }^{14}$. Al describir la invernada que la tripulación debió hacer en el golfo

12 Pigafetta, 1971. Primer viaje en torno del globo. Centro Editor de América Latina, Buenos Aires, pp. 22-30. En la misma sección Pigafetta incluye comentarios tales como: Fue visto, a los seis días, un gigante, pintado y vestido de igual suerte... o Éste era más alto aún y mejor construido que los demás... Sobre los orígenes del nombre "patagón", "patagonia", véase: Lestringant, 2003, op. cit.; Duviols, 1985. L'Amérique vue et rêvée. Promodis, Paris; Lida de Malkiel, 1952. Para la toponimia argentina: Patagonia, Hispanic Review, 20(4), pp. 321323, recuperado de www.jstor.org/stable/471147.

13 Castro, Hamon y Thomaz (Eds.), 2007, op. cit., p. 71.

14 Sobre la transformación de la experiencia en el Estrecho en un nuevo relato, María Jesús Benites afirma: El relato se nutre de la experiencia directa de los viajeros en territorios inexplorados para reconstruir un nuevo relato, diferido en el tiempo y alejado del escenario en el que transcurren los hechos que se narran. [...] El texto es el resultado de un ejercicio sucesivo de comprensión, que transforma a Transilvano en un lector-autor, no en un viajero, quien reelabora y re-escribe lo escuchado y, quizá, lo leído. Benites, 2013. 'La mucha destemplanza de la tierra': una aproximación al relato de Maximiliano de Transilvano sobre el descubrimiento del estrecho de Magallanes. Orbis Tertius, XVII(19), 200-207, p. 203.

15 Transilvano, 2018. Carta escrita por Maximiliano Transilvano de cómo y por qué y en qué tiempo fueron descubiertas y halladas las islas Molucas, donde es el propio nacimiento de la especiería, las cuales caen en la conquista y marcación de la corona real de España. Y divídese esta relación en veinte párrafos principales. En AA.VV., 2018. La primera vuelta al mundo. Miraguano-Polifemo de San Julián, el secretario también hace hincapié en el extraordinario tamaño de los habitantes de la región. En sus palabras: vieron algunos indios que andaban por la ribera cogiendo de las conchas que por alli había, los cuales eran de muy valientes cuerpos como gigantes, y andaban vestidos de pellejos de animalias fieras, y su color era algo tostada y morena, más de lo que el sitio de aquella tierra y región requería y demandaba ${ }^{15}$. Algunas líneas después, Transilvano vuelve a hacer referencia a la grandeza de sus cuerpos al narrar la captura de tres gigantes cuyos pasos eran tan grandes que apenas podían los nuestros trotando tener con ellos ${ }^{16}$.

En el transcurso de los tres siglos que siguieron a la hazaña magallánica, las aseveraciones del vicentino y de Transilvano fueron refrendadas (o refutadas) por el testimonio de los exploradores españoles tanto como de los viajeros holandeses, ingleses y franceses que merodearon las costas patagónicas ${ }^{17}$. En el caso de la corona española, mientras las referencias al

Ediciones, Madrid, pp. 13-56, p. 26. En 1550 la carta se publicó en el primer volumen de las Navegaciones y Viajes de Giovanni Battista Ramusio.

16 Ibidem, p. 28.

17 En el caso de la corona española, una vez concluida la circunnavegación magallánica fueron seis las exploraciones que partiendo tanto de Europa como de América occidental tuvieron por objetivo recorrer y profundizar el conocimiento que se tenía de la región magallánico-fueguina. Entre 1526 y 1540 desde España fueron enviadas las expediciones dirigidas por Francisco García Jofré de Loayza (1526), Simón de Alcazaba (1535) y Alonso de Camargo (1540). Las dos expediciones enviadas desde Chile fueron aquella ordenada por Pedro de Valdivia y comandada por Francisco de Ulloa, que se desarrolló entre fines de 1553 y principios de 1554, y la expedición a cargo del comandante Juan Ladrillero, que fue enviada por el gobernador de Chile García Hurtado de Mendoza y se desarrolló entre 1557 y 1558. Urbina, 2013. Expediciones a las costas de la Patagonia Occidental en el período colonial. Magallania, 41(2), pp. 51-84, p. 55. En 1579 partió desde el puerto de El Callao la expedición de Pedro Sarmiento de Gamboa, que no solamente tuvo por objetivo reconocer la entrada al Estrecho por Occidente, sino que, en vistas de los ataques perpetrados por Drake en su paso por las costas del Pacífico americano, debía estudiar la zona para prevenir futuras incursiones inglesas. Sarmiento de Gamboa, 2005. Viaje al estrecho de Magallanes y noticia de la expedición que después hizo para poblarlo. Estudio preliminar de José Luis Lanata; artículos anexos y notas de Rubén A. Arribas, Eudeba, Buenos Aires, pp. 18-31. 
tamaño de los habitantes de la región presentes en las relaciones de Juan Ladrillero y Pedro Sarmiento de Gamboa permanecieron sin publicar, cronistas tales como Francisco López de Gómara (1552), Gonzalo Fernández de Oviedo (1557) y Antonio de Herrera y Tordesillas (1601) formularon sus propias versiones de la experiencia patagónica, que también fue retomada por Giovanni Battista Ramusio en el primer volumen de sus Navegaciones y Viajes (1550) ${ }^{18}$.

Por su parte, la edición inmediata de los viajes de circunnavegación ingleses y holandeses realizados en el último cuarto del siglo XVI matizó las miradas sobre el tamaño de los patagones. En 1578, Francis Drake recorrió las costas magallánicas en el marco del primer viaje de circunnavegación inglés, que completaría en 1580 y daría origen al relato incluido por Richard Hakluyt en su gran compilación de viajes Principall Navigations (1589) ${ }^{19}$. Casi cincuenta años después de concluido el viaje se publicaría The World Encompassed by Sir Francis Drake, being his next voyage to that to Nombre de Dios formerly imprinted; carefully collected out of the notes of Master Francis Fletcher, preacher in this imployment $(1628)^{20}$, único relato en el que Drake hace una referencia a los gigantes patagones, aunque disminuye su talla de 10 a 7 pies y acusa a los españoles de haber exagerado. En sus propias palabras:

Magallanes no estuvo del todo equivocado en llamarlos gigantes, ya que en general se diferencian del hombre común, tanto en estatura, tamaño y

18 Ramusio incluyó los relatos de Pigafetta y Transilvano en el primer volumen de sus Navegaciones y Viajes.

19 Este llevó por título The famous voyage of Sir Francis Drake into the South Sea, and there hence about the whole Globe of the Earth, begun in the yeere of our Lord, 1577. El título completo de la monumental obra de Hakluyt era: Principall Navigations, Voiages and Discoveries of the English Nation, Made by Sea or over Land, to the most remote and farthest distant Quarters of the earth at any time within the compasse of these 1500 yeeres. La segunda edición de la obra fue publicada en tres volúmenes entre 1598 y 1600 bajo el título: The Principal Navigations, Voyages, Traffiques, and Discoveries of the English Nation.

20 El relato del viaje de circunnavegación de Drake también apareció en la compilación de viajes de Richard Hakluyt fuerza, como en la fealdad de su voz, pero no son tan monstruosos y gigantes como se ha informado, habiendo algunos ingleses tan altos como cualquiera de los que podíamos ver, sin embargo, los españoles jamás creyeron que algún inglés iba a llegar hasta aqui para refutarlos ${ }^{21}$.

El rédito económico y geopolítico que supuso la empresa del corsario inglés alentó a Inglaterra a continuar merodeando las costas patagónicas, lo que resultó en el segundo viaje de circunnavegación inglés, esta vez bajo la dirección de Sir Thomas Cavendish (1586-1588). Bajo el título The worthy and famous voyage of Master Thomas Candishe made round about the globe of the earth, in the space of two yeeres and lesse then two monethes, begun in the yeere 1586, su derrotero también fue incorporado por el gran compilador inglés Richard Hakluyt tanto en la primera como en la segunda edición de sus Principall Navigations, realizadas en 1589 y 1598 respectivamente ${ }^{22}$. El relato fue incluido un año después de la segunda edición en el octavo volumen del India Occidentalis o Americae (1599), monumental compilación de relatos de viaje dirigida y ejecutada por la familia de grabadores de Theodore De Bry. Al igual que en el caso de Drake, el relato de Cavendish hace una muy somera alusión al tamaño de los habitantes del Estrecho, que son descriptos como salvajes de estatura razonable $e^{23}$. También da cuenta del fracasado intento de Pedro Sarmiento de Gamboa por poblar la zona, pues solo encontró a los escasos y famélicos sobrevivientes

publicada en 1589. En realidad, poco después de arribar a Inglaterra, las hazañas y figura de Drake habían sido elogiadas por Nicholas Breton, quien en 1580 había publicado $A$ discourse in commendation of the valiant as vertuous minded gentleman, Maister Frauncis Drake. En el caso de The World Encompassed, la obra se basó en las notas de Francis Fletcher, que navegó con Drake, y fue compilada por el sobrino de este último.

21 Drake, 1652. The World Encompassed by Sir Francis Drake, collected out of the Notes of Master Francis Fletcher. Nicholas Bourne, Londres, p. 28. Ésta, como todas las traducciones del artículo, ha sido realizada por la autora.

22 Hakluyt, 1589, op. cit., pp. 809-810.

23 Ibidem, p. 810. 
de la Ciudad del Rey Don Felipe, fundada por el español en $1584^{24}$.

En el caso de Holanda, desde el despegue inicial de las Provincias Unidas tras la firma del Tratado de Utrecht en 1579, la presencia de navíos en los contornos meridionales de América se volvió cada vez más activa. Las primeras expediciones en bordear las costas de la región patagónica fueron aquellas de Olivier van Noort (1598), Simón de Cordes $^{25}$ (1598) y Sebalt de Weert (1600). En 1615, Joris van Spilbergen se convertiría en el quinto navegante en circunnavegar la Tierra, cruzando para ello las aguas del Estrecho y, al año siguiente, Jakob Le Maire y Willem Cornelisz Schouten también bordearían la región patagónica para, a diferencia de sus predecesores, atravesar las aguas que conectan ambos océanos por el desde entonces llamado cabo de Hornos (Cap Horn) ${ }^{26}$. En mayor o menor medida, el encuentro de estos viajeros con las poblaciones locales se definiría a partir de ciertos episodios puntuales, divulgados al público general a través de la publicación de relatos de viaje en formato individual o de su inclusión en las grandes compilaciones del período.

En la búsqueda de una ruta alternativa a las islas Molucas, los viajes de las compañías comerciales de las Provincias Unidas de los Países Bajos dieron origen a relatos e imágenes en los que, entre otros objetivos, se intentó dar cuenta de las costumbres de las poblaciones patagónico-fueguinas y de los posibles recursos del área en vistas de un eventual control del pasaje interoceánico. Sobre este último

24 Sobre este punto, resulta de interés destacar la alteración de la toponimia realizada por Cavendish en su paso por el Estrecho y reflejada luego en su relato del viaje. En especial, la Ciudad del Rey Don Felipe que pasó a llamarse Port of Famine en alusión al estado en que el inglés encontró a los escasos sobrevivientes de la efímera colonia española.

25 Cordes fue sucesor de Jacobo Mahu.

26 Ratto, 1930. Actividades marítimas en la Patagonia durante los siglos XVII y XVIII. Guillermo Kraft, Buenos Aires.

27 Córdova-Bello, 1965. Compañías holandesas de navegación: Agentes de la colonización neerlandesa. Escuela de Estudios Hispanoamericanos, Sevilla, p. 10. En cuanto a las mejoras técnicas, Córdova-Bello menciona que, para este mismo período, también habían perfeccionado los sistemas de protección y conservación de los cascos a base de un nuevo tipo de revestimiento. A su vez, es de interés señalar que hacia 1611 las Provincias Unidas disponían de 16.000 unidades navales, con una posibilidad de carga total de dos millones de lasten, aspecto que refrendaba su punto resulta de interés señalar que desde fines del siglo XVI los holandeses descollaron en la fabricación de embarcaciones. Introdujeron una serie de innovaciones en las naves que superaron a las portuguesas y fueron los creadores del fluyt, proyectado exclusivamente para el transporte de mercancías ${ }^{27}$.

En cuanto a la presencia del Reino de los Gigantes en distintos soportes textuales resta señalar que cosmógrafos franceses tales como André Thevet defendieron la existencia de los gigantes patagones en sus cosmografías universales $^{28} y$, aun a principios del siglo XVIII, el ingeniero Amedée-François Frézier adscribiría a esta creencia en su Relation du voyage de la mer du Sud aux côtes du Chili, du Pérou et de Brésil, fait pendant les années 1712, 1713 \& 1714. Ouvrage enrichi de quantité de planches en taille-douce (1716). Dentro de este conjunto un tanto heterogéneo de géneros e interpretaciones, al menos en el siglo XVII, los relatos de los viajeros ingleses y holandeses fueron los de mayor impacto en términos editoriales, aunque el punto de referencia (o partida) de todos ellos nunca dejó de ser la experiencia inaugural de Pigafetta y el testimonio indirecto de Transilvano ${ }^{29}$.

La presencia de un Gigantum Regio en las narrativas de los viajes de exploración tuvo, a su vez, un corolario cartográfico, evidenciado en los mapas de América (y de la región patagónica en particular) manuscritos o impresos en los principales centros económicos y culturales europeos de

supremacía en los mares.

28 En la sección dedicada al Nuevo Mundo de su Cosmographie Universelle (1575), André Thevet se dedica a probar la existencia de gigantes en las costas australes de América meridional.

29 Según Lestringant, 2012. Les Patagons de la carte (15201620). En Barthe y Mason (Dirs.). Patagonie. Images du bout du monde. Musée du quai Branly-Actes Sud, París y Arles, pp. 12-27, p. 26, Lo que llama la atención, como de costumbre, en la iconografía de los Grandes Descubrimientos, es la extraordinaria estabilidad de la imagen del patagón durante dos o tres siglos. El viaje de Magallanes, tal como nos fue transmitido por Antonio Pigafetta, acompañado de algunas fuentes conexas, como Maximiliano Transilvano, Pedro Mártir de Anglería y Antonio de Herrera, fijó por mucho tiempo sus rasgos. En cuanto a los grabados incluidos en los relatos de viaje, se destacan particularmente aquellos que acompañaron las ediciones de la Histoire d'un voyage aux Isles Malouines (1770) de Antoine-Joseph Pernety. 
mediados del siglo XVI y fines del XVII ${ }^{30}$. En cuanto a las producciones cartográficas manuscritas, fue el cartógrafo Diego Ribero quien, en 1529, introdujo a los patagones en su Padrón Real o mapa maestro y describió la región como habitada por hombres de grandes cuerpos, casi gigantes [quienes] visten de pieles de los animales de la tierra. Ribero fue, además, el primero en designar al estrecho de Fernando de Magallanes bajo ese nombre ${ }^{31}$.

Por su parte, el cosmógrafo sevillano Alonso de Santa Cruz incluiría un mapa del Estrecho y de la tierra o isla al mediodía del estrecho de Magallanes en su Islario general de todas las islas del mundo, obra manuscrita producida c. 1540. Si bien el mapa no hacía referencia alguna a los habitantes de la región ni utilizaba topónimos vinculados al avistamiento de hombres de gran tamaño, el texto que lo precedía explicaba que se sabía de esta supuesta isla por relaciones de quatro armadas q'han pasado por este estrecho, la primera y que lo descubrió fue Hernando de Magallanes portugués de nación q yva en demanda de las yslas de los Malucos y o de la especeria.... Sobre la talla de los habitantes de la región explica: cerca del puerto de S. Julian hallaron abitar una gente llamada Patagones muy agreste que habitaban en unas viles casas o choças a manera de las cavañas. Las cavañas de los pastores cubiertos con pellejos y de estatura algo mayores que los mayores de nosotros los quales tambien vido el capitán Loaysa pasando por este estrecho el año de mil e quinientos y veynte e sis y vio en esta tierra y o isla muchos humos y fuegos... ${ }^{32}$.

Según ha señalado Surekha Davies, la ilustración más temprana de un patagón en un mapa se encuentra en el mapamundi de 1544

30 Davies, 2016. Renaissance Ethnography and the Invention of the Human: New Worlds, Maps, and Monsters. Cambridge University Press, Cambridge, p. 163.

31 Martinic, 2004. Archipiélago patagónico. La última frontera. Ediciones de la Universidad de Magallanes, Punta Arenas.

32 Santa Cruz, c. 1540, Islario general de todas las islas del mundo, Biblioteca Nacional de España. Manuscrito de 111 mapas coloreados a la aguada, tamaño total $28 \times 21 \mathrm{~cm}$, ff. 248v-349r.

33 Davies, 2016, op. cit., p. 164. Ricardo Cerezo Martínez estima que el mapamundi fue trazado en Sevilla y editado en Amberes. Actualmente se conserva en la Biblioteca realizado a partir de un dibujo de Sebastián Caboto, quien por entonces era piloto mayor de la Casa de Contratación en Sevilla ${ }^{33}$. Algunos años después, Sancho Gutiérrez incluiría una figura de similares características en su mapamundi de 1551 (Fig. 1). Ricardo Cerezo Martínez ha sugerido que, por la semejanza en las anotaciones marginales, ambos cartógrafos pudieron haber recurrido a las informaciones contenidas en el libro-registro de la Casa de Contratación, sin embargo, la riqueza de las notas de Gutiérrez supera aquella de las de Caboto $^{34}$. En 1587, Joan Martines, cosmógrafo del rey Felipe II de España, confeccionaría un atlas manuscrito en el que el topónimo Patagonum Chica ocuparía la región al sur de la cuenca del Plata.

Ahora bien, más allá de las posibles referencias a los patagones en estos u otros mapas producidos por la corona española, lo cierto es que su circulación fue limitada tanto por tratarse de manuscritos cuanto por el celo de ésta frente a los posibles avances de sus rivales ${ }^{35}$. La validez de este último postulado debe, sin embargo, matizarse, pues el intercambio de información entre talleres cartográficos o potencias rivales fue mucho más fluido de lo que a primera vista parece. Tal como ha señalado Ricardo Cerezo Martínez la información geográfica no permaneció hermética para los cronistas y cosmógrafos europeos afectos a la corona española: Pedro Mártir de Anglería, Francisco Antonio Pigafetta, Pedro Apiano, Gerardo Mercator, Abraham Ortelius, entre otros, tuvieron acceso a las fuentes geográficas de la Casa de Contratación ${ }^{36}$.

La circulación de informaciones $y$ mapas también se observa en casos vinculados específicamente al Estrecho. La carta de la

Nacional de Francia. Cerezo, 1994. La cartografía náutica española en los siglos XIV, XV y XVI. Consejo Superior de Investigaciones Científicas, Madrid, p. 262.

34 Ibidem, p. 210. Véase también Wagner, 1951. A Map of Sancho Gutiérrez of 1551. Imago Mundi, 8(1), 47-49, p. 47.

35 Martinic, 2004, op. cit., pp. 101-102. El deseo de proteger la información del alcance de posibles rivales atañe particularmente a las informaciones sobre el Estrecho recabadas por expediciones españolas enviadas desde Chile y Perú a mediados del siglo XVI. Véase Portuondo, 2009. Secret Science: Spanish Cosmography and the New World. University of Chicago Press, Chicago, pp. 8-9.

36 Cerezo, 1994, op. cit., p. 139. 


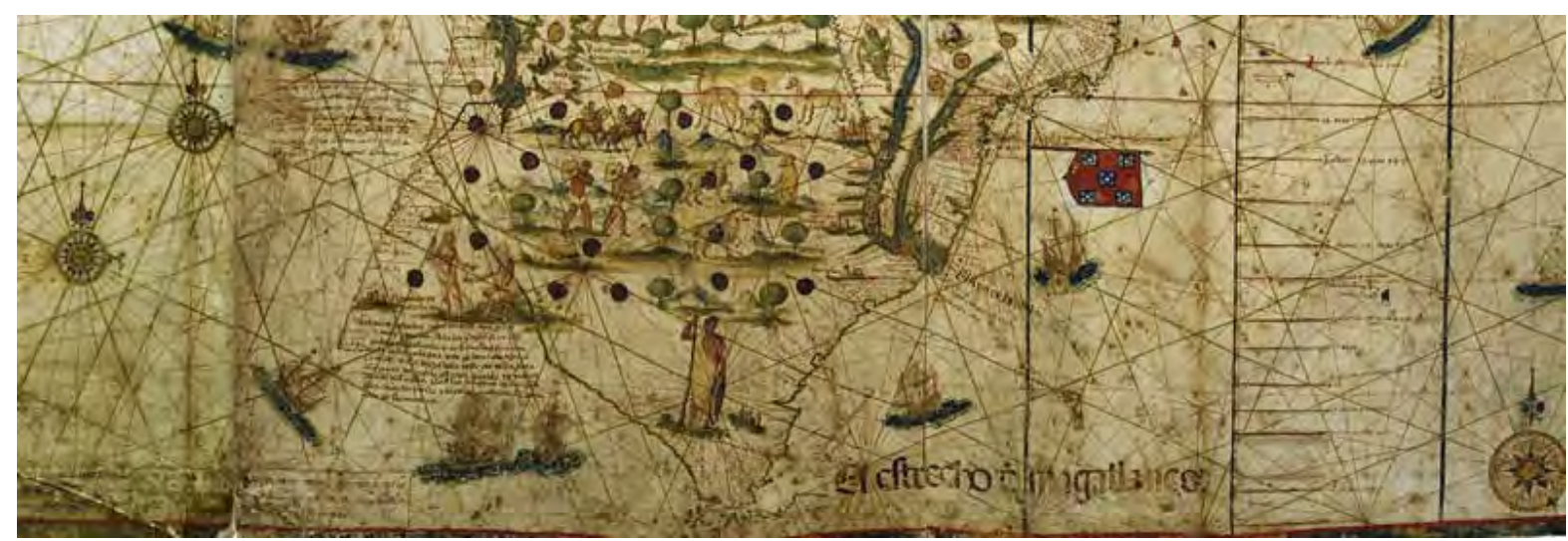

Fig. 1. Sancho Gutiérrez (1551). Carta Mapamundi. Detalle.

Mapa manuscrito actualmente conservado en la Biblioteca Nacional de Viena.

región magallánica confeccionada por Antonio Moreno en 1618, por ejemplo, da cabal cuenta de los "préstamos" e intervenciones cartográficas realizadas tanto por la corona española como por sus rivales en torno a espacios estratégicos en términos geopolíticos. En vísperas de la expedición liderada por los hermanos Bartolomé y Gonzalo Nodal en respuesta al descubrimiento holandés del cabo de Hornos, Moreno, quien fuera cosmógrafo de hacer cartas de la Casa de Contratación, adaptó el mapa utilizado en aquel entonces por Schouten y Le Maire. A su vez, en la expedición también tomaron parte dos pilotos flamencos, que debieron hacer un padrón de la parte ya navegada por los holandeses y que luego fue puesto en limpio por el propio Moreno $^{37}$. Por otra parte, la información recabada por la corona española también llegó a manos de cartógrafos flamencos como Petrus Plancius quien, en 1592, publicó un mapamundi basado en cartas geográficas portuguesas y españolas, sustraídas a los hispano-lusos ${ }^{38}$. Tal como ha señalado Günter Schilder para el caso de Cornelis Claesz, en ocasiones, el material cartográfico podía ser inclusive comprado. En efecto, fue en esta misma época que el editor adquirió veinticinco mapas del

37 Ibidem, pp. 119-120.

38 Córdova-Bello, 1965, op. cit., p. 12.

39 Schilder, 2017. Early Dutch Maritime Cartography: the North Holland School of Cartography (c.1580-c.1620). Brill, Hes \& De Graaf, Leiden, p. 155.

40 La monumental compilación de Navegaciones y Viajes (1550-1559) de Giovanni Battista Ramusio o la colección realizada por la familia De Bry entre 1590 y 1634 se presentan como claros ejemplos de ello.

41 En relación con este último punto, resulta necesario aclarar cartógrafo portugués Bartolomeo Lasso ${ }^{39}$.

En el mundo de la cartografía impresa, cuyo auge se dio principalmente por fuera de la península ibérica, la confección de mapas en los que estuvieran presentes elementos propios de los nuevos descubrimientos estuvo motivada, al igual que en las grandes compilaciones de viaje $e^{40}$, por la avidez comercial de impresores y editores, dispuestos a ofrecer al público interesado imágenes del Nuevo Mundo ${ }^{41}$. Ahora bien, al margen de las redes comerciales en las que circularon los mapas sobre el Gigantum Regio, es en torno a su esfera de producción que conviene detenerse para examinar los mecanismos de construcción de lo que podría denominarse un espacio cartográfico icónico. Interesan, en este sentido, los procesos epistemológicos de escritura cartográfica ${ }^{42}$, vinculados desde las perspectivas abiertas por la historia cultural a determinados contextos de producción, traducción y circulación de información sobre el Nuevo Mundo ${ }^{43}$. En términos generales, todo mapa de América requirió de la experiencia directa del viaje ultramarino en sus diversas variantes y géneros, pues en tierras jamás descriptas por los Antiguos debieron necesariamente prevalecer $\mathrm{o}$

que los mapas publicados en estas compilaciones y relatos, o aun aquellos que circularon separadamente, no estaban destinados a la navegación sino al consumo de un público lector general.

42 Lois, 2015. Quinta pars o terrae incognitae? La cuestión de la verosimilitud en la representación cartográfica de lo desconocido. Terra Brasilis, 4, recuperado de http:// journals.openedition.org/terrabrasilis/1084

43 Jacob, 1996. Toward a Cultural History of Cartography. Imago Mundi, 48, 191-198, p. 193. 
reivindicarse los testimonios de quienes habían visto con sus propios ojos los territorios recientemente descubiertos ${ }^{44}$. En otras palabras, a diferencia de la Tierra Austral incógnita (cuya existencia había sido teorizada por el saber clásico), en el caso de América la cosmografía temprano-moderna debió recurrir al testimonio del auctor o testigo para producir en términos cartográficos una imagen verosímil del Nuevo Mundo ${ }^{45}$.

En cuanto al área magallánico-fueguina, el impacto de la experiencia inglesa y holandesa en la consolidación de una iconografía específica sobre los habitantes de la región invita a reflexionar en múltiples sentidos. Por un lado, permite examinar la influencia recíproca entre representación y experiencia a partir de la participación de agentes intermedios tales como grabadores, impresores y editores. Por el otro, arroja luz sobre el proceso de síntesis (en términos cartográficos) de un acontecimiento histórico ocurrido en un territorio determinado. Los contextos que auspiciaron las experiencias de exploración de la región patagónica, los espacios de edición y circulación de las cartografías y relatos seleccionados, y sus efectos en la construcción de los gigantes patagones devienen, en este sentido, variables de análisis indispensables para comprender a la cartografía temprano moderna como la puesta en imágenes de un tiempo histórico determinado ${ }^{46}$.

\section{HOLANDA Y LA CONSTRUCCIÓN DE UN REPERTORIO ICONOGRÁFICO ESPECÍFICO PARA PATAGONIA}

Estudios recientes en los campos de la historia y la etnografía han vinculado las imágenes

44 Sobre la importancia del testigo en la producción de un relato fidedigno véase Ginzburg, 2010. El hilo y las huellas. Fondo de Cultura Económica, Buenos Aires.

45 Sobre la importancia de la autopsia como forma de conocimiento en la modernidad temprana véase el capítulo II de Pagden, 1993. European Encounters with the New World. Yale University Press, New Haven y Londres.

46 Lo mismo sucedía con los grabados que acompañaban a los relatos de viaje. Van Groesen, 2012. The Representations of the Overseas World in the De Bry Collection of Voyages (1590-1634). Brill, Leiden-Boston, p. 124.

47 Davies, 2016, op. cit., p. 151.

48 Duvernay-Bolens desarrolla su tesis in extenso en Les Géants patagons: voyage aux origines de l'homme. Allí sugiere que el mito de los gigantes tuvo sus orígenes en la antigüedad clásica (Duvernay-Bolens, 1995. Les desarrolladas en torno a la región patagónica a los procesos de construcción de nuevos tipos de alteridad ocurridos en la modernidad temprana. En obras tales como Renaissance Ethnography and the Invention of the Human, Surekha Davies ha puesto el foco en la influencia del imaginario europeo previo a la expansión transoceánica en la creación del gigante patagón. Según Davies, fueron las descripciones sobre los habitantes de los confines dadas por Plinio en su Historia Natural (s. I) y la tradición bíblica las que alimentaron indirectamente el mito de los gigantes patagones ${ }^{47}$. Por hallarse en los límites de la humanidad a partir de su denominación misma (i.e. se trata de una "Tierra de gigantes" según el topónimo de Diego Ribero), el comportamiento de los hombres y mujeres de la región tal como fue descripto por Pigafetta y Transilvano reavivó el debate respecto de si se trataba o no de un pueblo monstruoso. Su ubicación en los confines de América meridional los emparentaba con los extraños seres descriptos por Plinio, pues tal como ha señalado Jacqueline Duvernay-Bolens el pueblo de los Patagones conserva de los esciápodos los rasgos invariables que los designan como el pueblo de las Antipodas ${ }^{48}$

Más allá del interés que despierta el debate en torno a la naturaleza de los patagones, el presente artículo busca examinar la transposición de textos a imágenes en la creación de un imaginario específico sobre aquella región del mundo. Este proceso de "traducción" de un relato de viaje a una carta geográfica no estuvo libre de las contradicciones, omisiones o adaptaciones propias de su contexto de producción. Tal como

\footnotetext{
Géants patagons: voyage aux origines de l'homme. Éditions Michalon, Paris, pp. 11 y 24), aunque también contempla los aportes del folclore medieval. Para la autora, su ubicación en los confines del mundo conocido, sin embargo, fue producto de los viajes de exploración, que revitalizaron el interés por aquellos hombres de gran tamaño al tiempo que lanzaron una serie de debates en torno a su status y condición. Duvernay-Bolens, 1988. Les Géants Patagons ou l'espace retrouvé: Les débuts de la cartographie américaniste. L'Homme, 28(106/107), pp. 156-173, p. 167. Los argumentos y preguntas formulados por Duvernay-Bolens fueron retomados por Davies quien, a partir del caso de los gigantes patagones, volvió sobre la pregunta en torno a la unicidad o pluralidad de la humanidad en el contexto del Renacimiento. Davies, 2016, op. cit., pp. 148-182.
} 
ha señalado Christian Jacob ${ }^{49}$, puesto que el mapa se encuentra directamente asociado a la cultura de su tiempo, a su biblioteca, a su enciclopedia, la identificación de estos textos de referencia, que forman parte de un horizonte cultural compartido, contribuye a descifrar el mapa, al desactivar la extrañeza de lo nunca visto por el reconocimiento de lo ya leído. En el caso de las imágenes cartográficas sobre el área magallánicofueguina, resultaron variables de peso tanto el auge holandés en la producción de cartas náuticas y mapas cuanto la consolidada popularidad que, entre fines del siglo XVI y comienzos del XVII, tuvieron las grandes compilaciones de viajes. En relación con los textos de referencia a partir de los cuales la cartografía holandesa construyó una imagen de los patagones conviene detenerse, en primer lugar, en la coyuntura en que tanto Levinus Hulsius (1603) como Pieter van den Keere (1614) y Nicolaes Visscher (1633), entre otros cartógrafos, articularon una imagen determinada de los habitantes del área magallánico-fueguina.

En términos generales, ha sido señalado ya cómo hacia fines del siglo XVI hubo una coyuntura favorable para la expansión ultramarina holandesa en el marco de la separación de las Provincias Unidas de la monarquía española ${ }^{50}$. Hasta la creación de la monopólica Compañía holandesa de Indias Orientales (VOC) en 1602, existieron diferentes compañías comerciales dispuestas a encontrar caminos alternativos en la ruta de las especias. Una vez consolidada la VOC, bajo el respaldo de Holanda, las Provincias Unidas lograron controlar las islas especieras de Oriente, factor que acrecentaba su interés por descubrir una ruta marítima alternativa a las ya conocidas y reforzaba, en consecuencia, la rivalidad con España. En palabras de Manuel Herrero Sánchez, para 1605 los neerlandeses ya se habian

49 Jacob, 1992. L'empire des cartes: approche théorique de la cartographie à travers l'histoire. A. Michel, Paris, p. 327.

50 Sobre el papel de la VOC (1602) en el despegue holandés, véase Zandvliet, 2007. Mapping the Dutch World Overseas in the Seventeenth Century. En Woodward (Ed.), The History of Cartography, Volume Three, Part 2, (14331462). Chicago University Press, Chicago.

51 Herrero, 1999, op. cit., p. 59.

52 Entre 1598 y 1601 Olivier van Noort dio la primera vuelta holandesa al globo. Joris van Spilbergen entre 1614 y 1617. apoderado del tráfico de las islas especieras de Ternate, Tidore y Amboina, en Indonesia $y$, en 1619, la fundación de Batavia (la actual Yakarta) sirvió para dotar a la VOC de un cuartel general desde el que empadronarse del control de las partidas de pimienta y de otro tipo de especias $^{51}$. En los relatos de sus experiencias de navegación alrededor del mundo fueron frecuentes las referencias al pasaje por las difíciles aguas en las proximidades del Estrecho, que se presentó como un camino posible al Maluco. Ha sido señalado ya cómo, entre 1598 y 1617, los holandeses realizaron dos circunnavegaciones al globo ${ }^{52}$. Hubo, además, otras expediciones a la zona del Estrecho que, si bien fracasaron en relación con sus objetivos comerciales iniciales, redituaron en la producción de nuevos relatos de viaje $e^{53}$.

Entre tanto, tal como ha señalado Jonathan Israel, a partir de 1598 la guerra hispanoneerlandesa comenzó a evolucionar con rapidez, convirtiéndose en el primer conflicto global de la historia cuyos diferendos se ampliaron hasta abarcar el mundo entero ${ }^{54}$. Cuando en 1616 Schouten y Le Maire descubrieron el cabo de Hornos, la respuesta española fue el inmediato envío de los hermanos Bartolomé y Gonzalo Nodal en una expedición que constatara lo descubierto por los holandeses en el extremo meridional de Tierra del Fuego. En principio, desde las incursiones de Drake en el Pacífico sur, a raíz de las cuales se había organizado la segunda expedición de Pedro Sarmiento de Gamboa, la Corona se había puesto por objetivo acrecentar el control y defensa de las costas meridionales de América.

La favorable coyuntura para la expansión y los recursos editoriales disponibles en los principales centros comerciales e intelectuales de las Provincias Unidas, dieron lugar a una serie de informes, relatos y crónicas que fueron

Willem Schouten y Jakob Le Maire cruzaron el Estrecho, navegaron hacia Oriente y regresaron a Europa entre 1615 y 1617 pero no a bordo de sus propias embarcaciones.

53 Se destaca la Relación histórica o verdadera y genuina consignación y descripción de aquella navegación, que cinco naves, el mes de junio del año 1598, partieron de Ámsterdam con la intención de atravesar el estrecho de Magallanes en dirección a las islas Molucas..., del navegante Sebalt de Weert.

54 Israel, 1997b. La República holandesa y el mundo hispánico: 1606-1661. Nerea, Madrid, p. 26. 
capitalizados por editores holandeses y la familia De Bry, que los incluyó en su gran compilación de viajes a las Indias Occidentales y Orientales $(1590-1634)^{55}$. El médico y coleccionista Bernardus Paladanus, por ejemplo, proveyó a los De Bry de varios de los relatos de viaje que fueron utilizados en la confección del India Orientalis ${ }^{56}$. La compra de relatos a los editores más importantes de las Provincias Unidas también resultó un recurso práctico. Uno de los más prestigiosos de Ámsterdam, Cornelis Claesz, parece haber provisto al menos diez de los relatos de viaje (holandeses) incluidos en la colección India Occidentalis o Americae. Al respecto, Michiel van Groesen ha señalado que al menos ocho de los trece volúmenes de la colección de viajes publicada entre 1598 y 1609 estuvieron basados en los testimonios de los viajeros holandeses editados por Claesz ${ }^{57}$.

Junto a los relatos publicados también circularon grabados sobre alguna escena en particular, diseñados para acompañar las ediciones individuales $\mathrm{o}$ ser incluidos en las grandes compilaciones que por entonces eran garantía de éxito editorial. A su vez, dichas imágenes fueron tomadas por los cartógrafos holandeses, quienes las adaptaron e incluyeron en los mapas de la región. En la colección de viajes impresa por la familia de Theodore De Bry entre 1590 y 1634, los grabados utilizados para ilustrar las descripciones de los viajes al Nuevo Mundo alimentaron la producción holandesa de mapas sobre América ${ }^{58}$. En el caso del Gigantum Regio, los grabados presentes en los volúmenes VIII y IX del Americae, dedicados a las circunnavegaciones de Francis Drake y Thomas Cavendish y a los viajes de Sebalt de Weert y Olivier van Noort respectivamente, reaparecieron en los mapas holandeses publicados poco

55 A partir de 1590 la familia De Bry lanzó una monumental colección de relatos de viajes traducidos al latín y al alemán que publicó infolio en 25 volúmenes. Bajo el nombre Americae, trece fueron dedicados a los viajes europeos a las Indias Occidentales. Los doce restantes fueron agrupados bajo el título de India Orientalis y contenían relatos vinculados a las exploraciones de Asia y África.

56 van Groesen, 2012, op. cit., p. 118. Gotthard Artus von Dantziz y Carolus Cluisus también parecieran haber contribuido con relatos de viaje holandeses.

57 Ibidem, p. 121.

58 Ibidem, p. 354. tiempo después. En principio, se trataba de una práctica corriente entre los grabadores y editores holandeses, que utilizaron la iconografía de Frankfurt para decorar su material geográfico y cartográfico... ${ }^{59}$. A su vez, no era extraño que los humanistas que habían trabajado con los De Bry en las traducciones de los relatos de viaje reutilizaran aquellas imágenes para sus propios trabajos ${ }^{60}$.

Antes de analizar aquel proceso de transposición conviene detenerse brevemente en las imágenes referidas. Se trata de cuatro personajes emblemáticos y de una serie de figuras representativas de la fauna del lugar, tales como pingüinos y moluscos, cuyo consumo fue fundamental para la supervivencia de las expediciones europeas en la zona del Estrecho. Todos ellos fueron representados en el frontispicio del noveno volumen del Americae y/o en la sección destinada a los viajeros holandeses dentro de éste (Figs. 2 y 3). Tanto los elementos en las manos de las cuatro figuras como las acciones que realizan (i.e. un hombre arroja una lanza o traga una flecha, una mujer alimenta a un niño, etc.) evidencian que, más allá de algunas modificaciones, su composición ha sido realizada a partir de las descripciones de los viajeros (holandeses principalmente) a la zona. Aunque debe reconocerse, por otra parte, que en el caso de los relatos de Sebalt de Weert (1602), Olivier van Noort (1602), Willem Cornelisz Schouten (1616) y Joris van Spilbergen (1619), los grabados que acompañaron la publicación de sus viajes exacerbaron o distorsionaron las descripciones hechas sobre los habitantes del Estrecho y las costas australes de América meridional.

En el caso del fallido intento por circunnavegar el globo de Sebalt de Weert, la Relatio Historica fue publicada por la familia De Bry en Frankfurt en 1602 como parte del ya mencionado noveno tomo del Americae ${ }^{61}$. Una primera versión del relato, escrito por el cirujano

59 Ibidem, p. 352.

60 Ibidem, p. 364.

61 En 1598 Sebalt de Weert se había embarcado en la flota de Jacques Mahu, pero su navío se había separado del resto de la flota en las proximidades del estrecho de Magallanes. No pudiendo llegar al Pacífico y emprender la ruta hacia las Molucas, de Weert había capitaneado la nave nuevamente a través del Atlántico y regresado a Ámsterdam en 1600 con solo treinta y seis sobrevivientes. En los meses en los que estuvo en la zona del Estrecho, de Weert avistó la flota de van Noort, encaminada a emprender el primer viaje de circunnavegación holandés. 
de a bordo Barent Jansz Potgieter, había sido publicada en 1600 bajo el título de Wijdtloopigh verhael van tgende de vijf schepen. Los ocho grabados que acompañaron aquella primera edición fueron retomados por los De Bry, quienes los modificaron sustancialmente para exacerbar el poder de los navegantes holandeses frente a los habitantes de la zona ${ }^{62}$. En el mapa sobre el Estrecho incluido por los De Bry en el noveno tomo, reaparecían los cuatro personajes presentes en los grabados de 1600. En primer lugar, en el margen superior derecho figuraba una mujer alimentando a un niño con un ave descuartizada, composición cuyos orígenes se

62 van Groesen, 2005, Barent Jansz. en de familie De Bry. Twee visies op de eerste Hollandse expeditie 'om de West' rond 1600. De zeventiende eeuw, 21(1), 29-48; van Groesen, 2012, op. cit., pp. 272-273.

Fig. 2. Frontispicio incluido en la sección destinada a los viajes holandeses del noveno volumen del Americae o India Occidentalis realizado por la familia De Bry. Viuda e hijos de Theodore De Bry (1602).

Americae nona et postrema pars, qua de ratione elementorum, de novi orbis natura, de hujus incolarum... Frankfürt: Matthäus Becker. John Carter Brown Library.
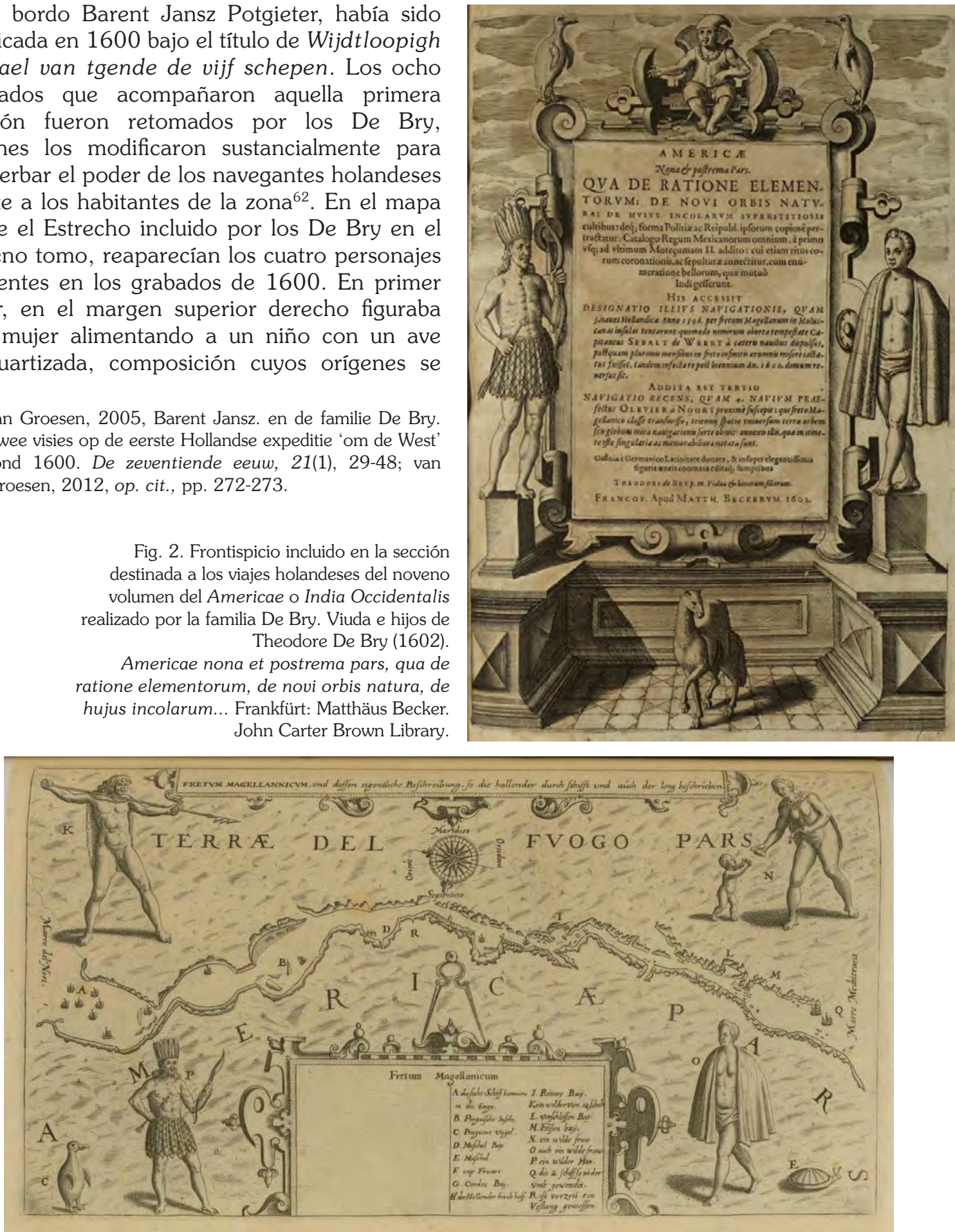

Fig. 3. Mapa incluido en la sección destinada a los viajes holandeses del noveno volumen del Americae o India Occidentalis realizado por la familia De Bry. Viuda e hijos de Theodore De Bry (1602).

Americae nona et postrema pars, qua de ratione elementorum, de novi orbis natura, de hujus incolarum... Frankfürt: Matthäus Becker. John Carter Brown Library. 
encuentran en una descripción incluida en el relato del viaje de De Weert escrito por Potgieter (Fig. 4) ${ }^{63}$. La escena había ocurrido durante la larga invernada de la tripulación en el área del Estrecho, cuando tras capturar y llevar a bordo a una mujer con sus dos hijos:

le trajeron de la canoa un ave, la desplumó de sus plumas más grandes y en línea recta, desde el ala derecha, la dividió por el medio del pecho hasta el ano y le sacó las entrañas; descartó el folículo de la bilis, los intestinos y el corazón. Inmediatamente asó el hígado sobre las llamas y lo devoró tan ávidamente que sus labios abundaban en sangre. Luego tomó el vientre y lo demás del alimento, una extremidad con los dientes y la otra con la mano izquierda (...) El resto del cuerpo del ave lo tomó a mordiscos y lo desgarró con tanta abominación que la sangre, que manaba abundantemente, cayó por su pecho. Los infantes comían del ave de la misma manera. El mayor de ellos tenía cuatro años y medio ${ }^{64}$.

El episodio, que aparece representado con modificaciones en el noveno volumen del Americae (1602) (Fig. 5), sería retomado un año después por el cartógrafo y editor Levinus Hulsius, quien en 1603 construyó su propia síntesis de Patagonia a partir de los grabados de la familia De Bry (Fig. 6). Las imágenes presentadas en la colección de viajes de Hulsius se basaron en gran medida en los grabados hechos por Georg Keller, quien también había trabajado para la familia de impresores ${ }^{65}$. Sin embargo, el mapa en el que reaparecían los personajes de los grabados del viaje de De Weert y su adaptación por parte de los De Bry fue incluido por Levinus Hulsius para ilustrar el relato de viaje de Thomas Cavendish, que junto con los viajes de van Noort y de Weert conformaban el sexto volumen de su más económica colección Sammlung von sechs

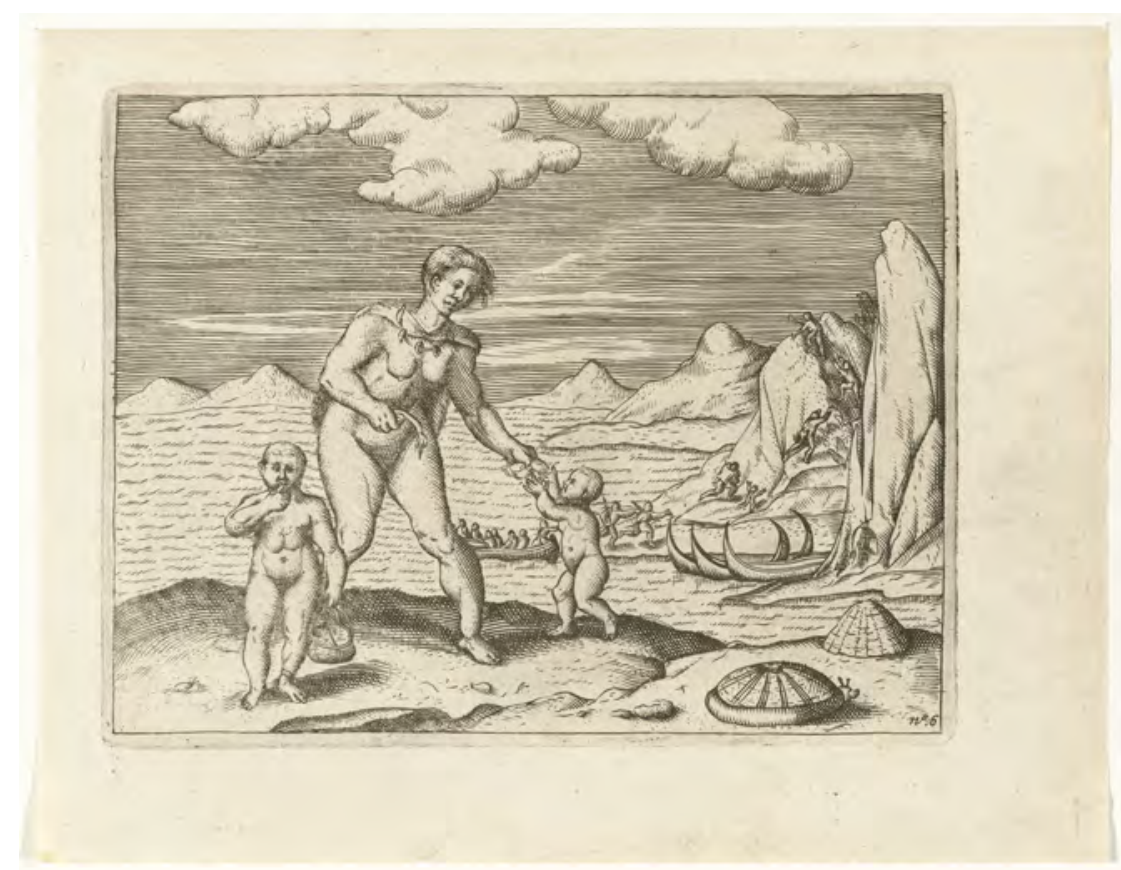

Fig. 4. Barent Jansz Potgieter (1600). Wijdtloopigh verhael van tgende de vijf schepen. Mujer alimentando a sus niños. Rijksmuseum.
63 Se trata de Relación histórica o Verdadera y genuina consignación y descripción de aquella navegación... publicada en Frankfurt por Matthaeus Beckerus en 1602. De Weert era miembro de la Compañía de Rotterdam, mientras que van Noort había sido enviado por la Compañía Magallánica (Magelhaensche Compagnie).
64 De Weert y Schouten, 2010. Descubrimiento del Cabo de Hornos. Relación histórica de dos navegaciones holandesas. Eudeba-Colección Reservada del Museo del Fin del Mundo, Buenos Aires, p. 105.

65 van Groesen, 2012, op. cit., p. 350. 


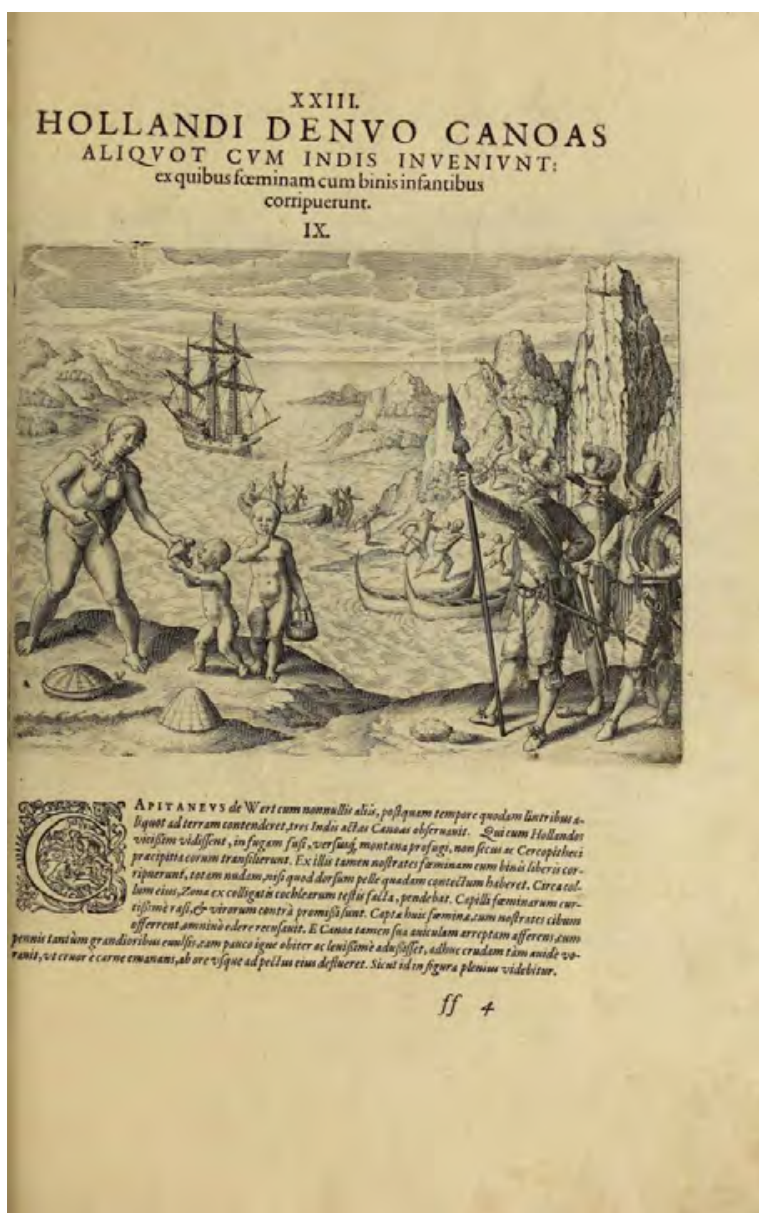

Fig. 5. Hollandi denvo canoas aliquot cum Indis inveniunt. Viuda e hijos de Theodore De Bry (1602). Americae nona et postrema pars, qua de ratione elementorum, de novi orbis natura, de hujus incolarum... Frankfurt: Matthäus Becker. John Carter Brown Library.

und zwanzig Schiffahrten in verschiedene fremde Länder durch Levinus Hulsius und einige Andere, aus dem Holländischen ins Deutsche übersetzt und mit allerhand Anmerrkungen versehen. Esto explicaría por qué el mapa contiene referencias explícitas

66 En el mapa, el topónimo acompaña la ilustración de una fortificación. Sobre el frustrado intento de colonización español, la relación de viaje de van Noort también hace alusión al hallazgo de los sobrevivientes de la ciudad fundada por Pedro Sarmiento de Gamboa. Al respecto, van Noort explica: Un año entero pasaron así estos infelices, sustentándose de hojas, frutas, raíces $y$ algunas aves, cuando podían matarlas: pero finalmente, viendo que de 400 personas que se habian establecido

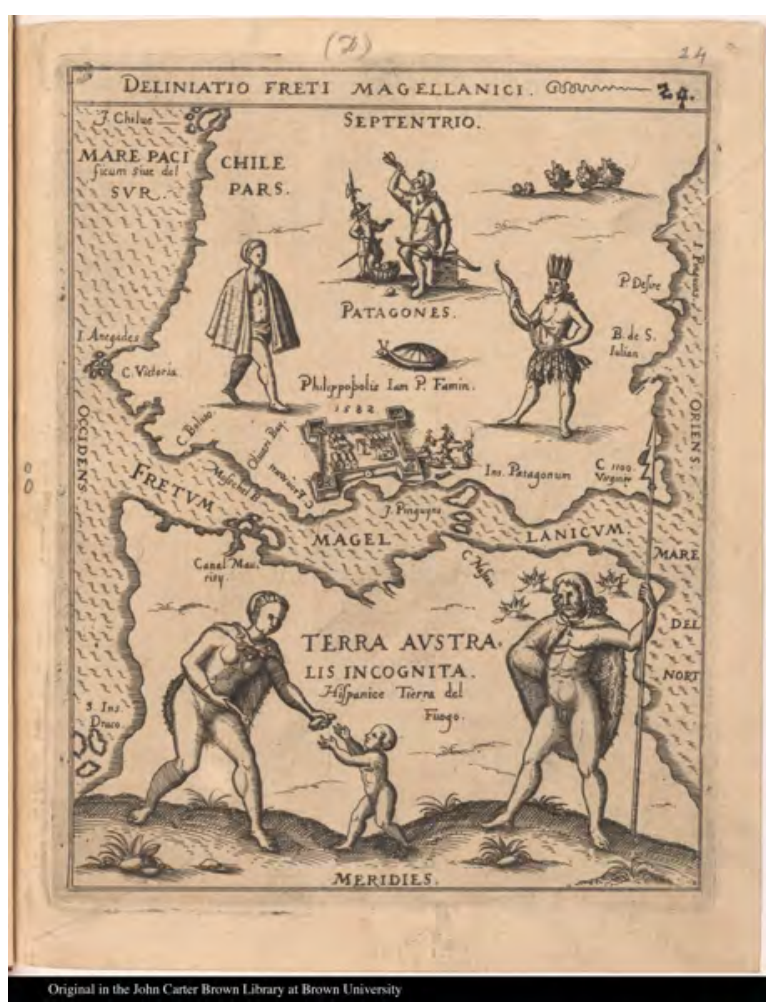

Fig. 6. Levinus Hulsius (1626 [1602]). Delineatio Freti Magellanici. Frankfurt: Hartmanno Palthenio. John Carter Brown Library.

a la ciudad española del Rey Don Felipe, señalada en el mapa como Philippopolis ${ }^{66}$ y su refundación bajo el nombre de Port of Famine en el marco de las incursiones inglesas lideradas por Cavendish y el hallazgo de algunos de los pocos sobrevivientes de la colonia de Sarmiento de Gamboa. En el mapa de Hulsius también aparece la isla de los Pingüinos, bautizada asî por Sebalt de Weert, y mencionada luego en la expedición de van Noort, que en su paso por ella se había abastecido de más de dos mil aves ${ }^{67}$.

El mapa de Hulsius también retoma al hombre robusto erguido con una lanza en la mano que De Bry había ubicado en el margen

alli, solo quedaban ya 23 y entre ellas dos mujeres, se determinaron a tomar el camino del Río de la Plata, según lo refirió a los ingleses uno de aquellos veintitrés, llamado Hernando, que habiendo quedado alli solo, fue apresado y conducido a Inglaterra. En cuanto a los demás, no se ha sabido su paradero. Sarmiento de Gamboa, 2005, op. cit., p.

67 Martinic, 2012. Los holandeses en las islas de los Pingüinos (1599-1615). Magallania, 40(2), 7-22, p. 10. 
superior izquierdo de su propia carta del Estrecho. Esta imagen también tenía un antecesor directo en el grabado del viaje narrado por Barent Jansz Potgieter, aunque no únicamente. Los dos personajes restantes (i.e. un patagón con falda y tocado de plumas y una mujer con capa y pechos caídos) también habían aparecido en el relato de Potgieter para ilustrar distintos episodios del encuentro de los holandeses con los habitantes del área magallánico-fueguina (Fig. 7). Sus orígenes, sin embargo, parecen encontrarse en otros espacios de producción. En efecto, tanto el hombre vestido de plumas como la mujer cubierta (únicamente) por una capa fueron insertos en otros escenarios geográficos hechos por los De Bry aun antes de los viajes holandeses.

En lo que respecta a la figura del hombre vestido de plumas, la imagen bien podría haber respondido a un rasgo estereotípico atribuido a los habitantes de América en la modernidad temprana, ya sea por falta de información específica por parte de los grabadores o por el afán de crear un perfil homogéneo para el hombre americano68. En el octavo volumen del Americae, cuya editio princeps en latín data de 1599, dentro del conjunto de grabados que ilustran el viaje a Guyana realizado por Sir Walter Raleigh en 1595 se advierte la presencia de la misma figura para representar a uno de los nobles del reino preparando al emperador de la región previo a una ceremonia ${ }^{69}$.

Ahora bien, más allá de esta y otras posibles apariciones, lo cierto es que a partir de su incorporación al repertorio iconográfico magallánico-fueguino, pareció refrendarse la identificación de esta figura con aquella región. En efecto, del conjunto de figuras incluidas en el relato de Olivier van Noort para dar cuenta de las diversas poblaciones que habitaban el Estrecho, el hombre patagónico es, una vez más, aquella figura con tocado y falda de plumas ${ }^{70}$. Al igual que muchos de los relatos de sus contemporáneos, la circunnavegación de van Noort fue publicada por Cornelis Claesz en Ámsterdam en 1602 y traducida ese mismo año al francés bajo el título Description du penible voyage faict entour de l'univers ou

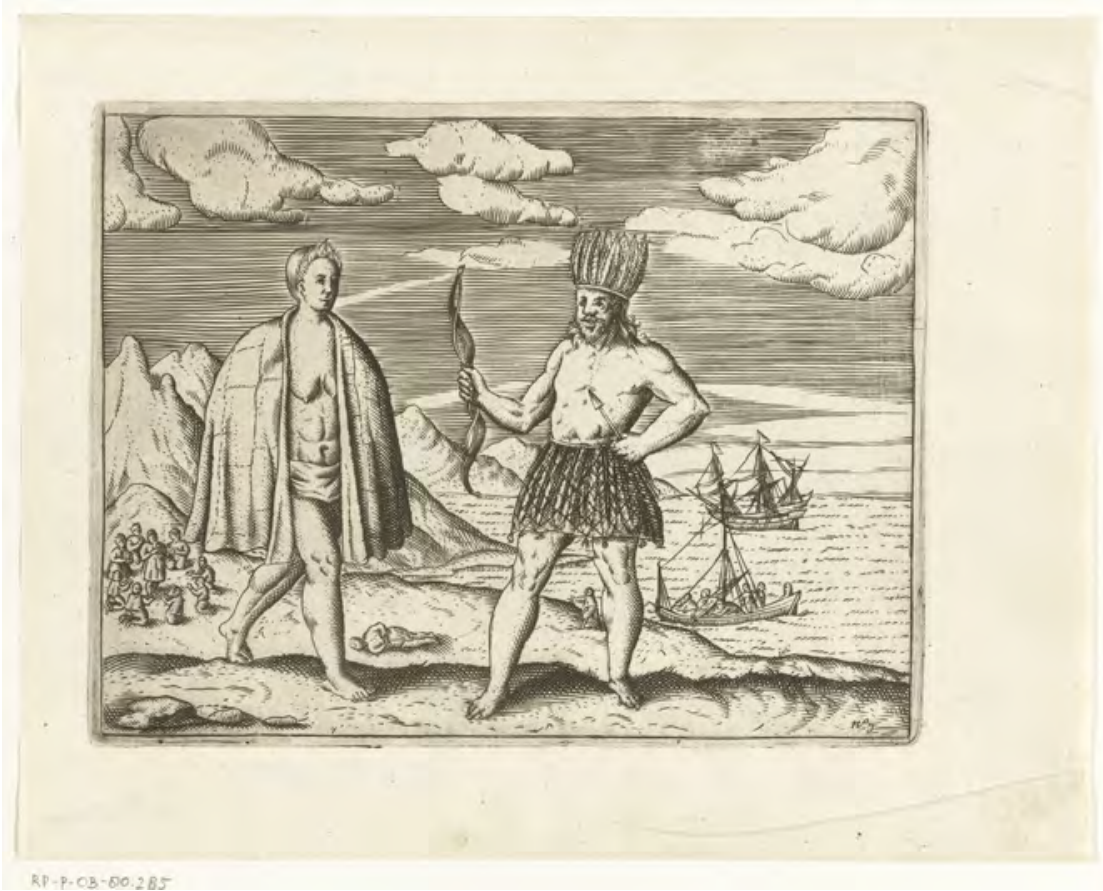

Fig. 7. Barent Jansz Potgieter (1600). Wijdtloopigh verhael van tgende de vijf schepen. Mujer con capa y hombre con tocado y falda de plumas. Rijksmuseum.
68 van Groesen, 2012, op. cit., p. 201.

69 La figura se encuentra hacia el final del volumen en la lámina XV, que lleva por título Quomodo imperator regni guianae, nobiles sous ornare \& praeparare soleat...
70 En la edición en francés del viaje de van Noort realizada en Ámsterdam en 1602, esta imagen se incluía junto a otras dos sobre los habitantes de la región. 


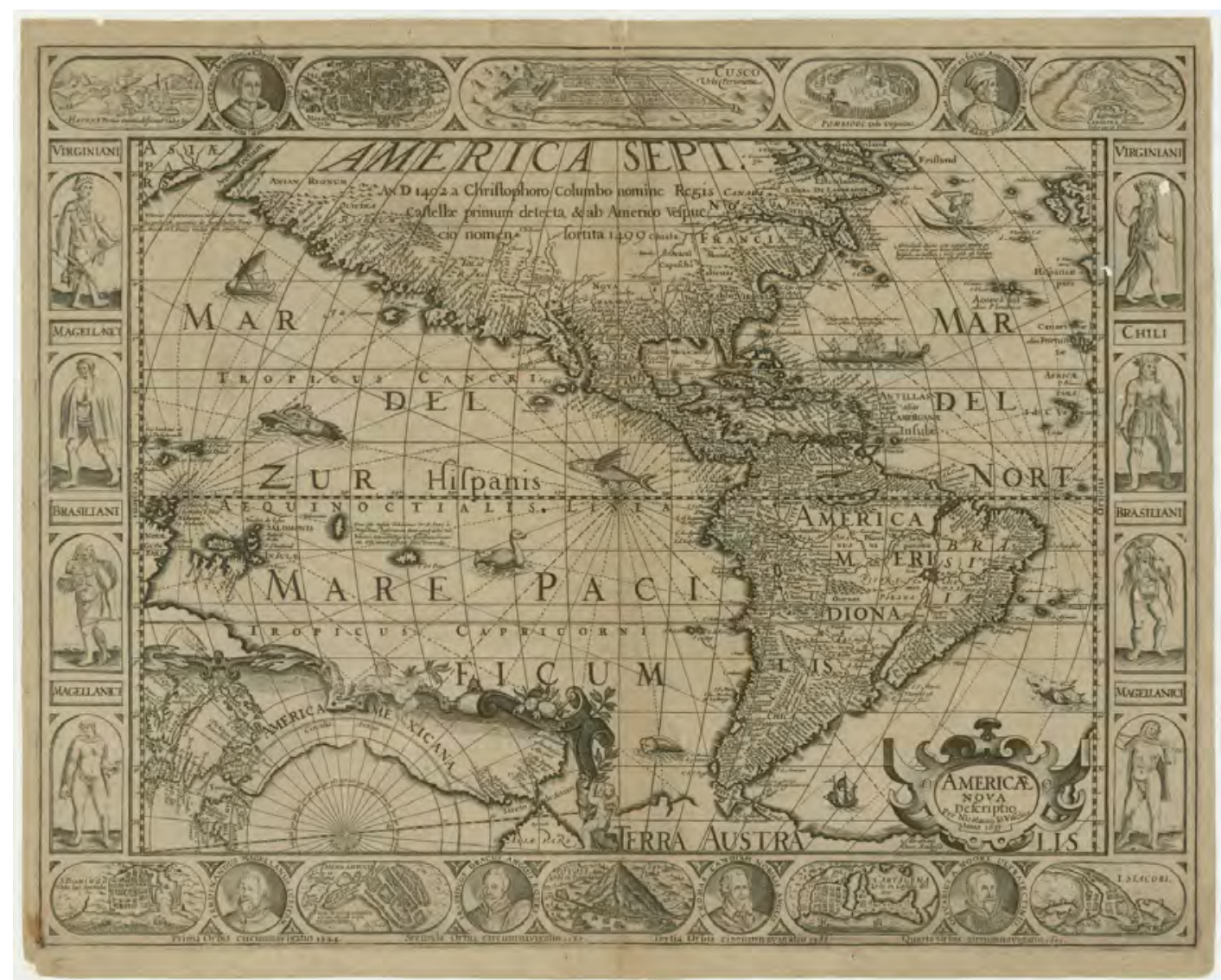

Fig. 8. Nicolaes Visscher (1633). Americae nova descriptio.

Ámsterdam (orig. Pieter van den Keere, 1614). John Carter Brown Library.

globe terrestre ${ }^{71}$. Además fue incluida por los De Bry en el noveno volumen de su Americae y, en 1603, en el sexto volumen de la mencionada colección Sammlung von sechs und zwanzig Schiffahrten in verschiedene fremde Länder..., compilación impresa en veintiséis partes editada por Hulsius entre 1598 y 1663. El uso frecuente de esta imagen para caracterizar el área también se observa en su reaparición en los márgenes del mapa de Nicolaes Visscher (1633) (Fig. 8), y aun en los grabados que hacia fines del siglo XVIII fueron utilizados por los viajeros franceses para dar testimonio de la condición y talla de los patagones ${ }^{72}$.

71 Ese mismo año también se hicieron ediciones en alemán y en latín. El título completo en holandés fue: Beschryvinghe Vande Voyagie Om Den Geheelen Werelt Cloot, Ghedaan Door Olivier Van Noort.

72 Los grabados insertos en la Historia de un viaje a las islas Malvinas (1770) de Antoine-Joseph Pernety son un claro ejemplo de ello. Véase Pernety, 1770. Histoire d'un
Tal como se observa en las Figs. 8 y 9 , en los mapas de Joris van Spilbergen (Fig. 9) y Nicolaes Visscher también aparecen con leves modificaciones los tres personajes restantes, que refuerzan la noción de un espacio cartográfico icónico creado para sintetizar las informaciones del área.

En el caso de la mujer con capa, se advierte su semejanza con el grabado del "sacerdote de Secotan" (Fig. 10) incluido por Theodore De Bry en su Admiranda Narratio (1590) y creado a partir de las acuarelas realizadas por John White en el asentamiento inglés de Virginia ${ }^{73}$. Asimismo, su silueta pareciera corresponderse con aquellas de

voyage aux Isles Malouines, fait en 1763 \& 1764; avec des observations sur le détroit de Magellan, et sur les Patagons...Saillant \& Nyon, Delalain, Paris.

73 Aucardo Chicangana, 2005. El festín antropofágico de los indios tupinambá en los grabados de Theodore De Bry, 1592. Fronteras de la Historia, 10, pp. 19-82, recuperado de http://www.redalyc.org/pdf/833/83301001.pdf 


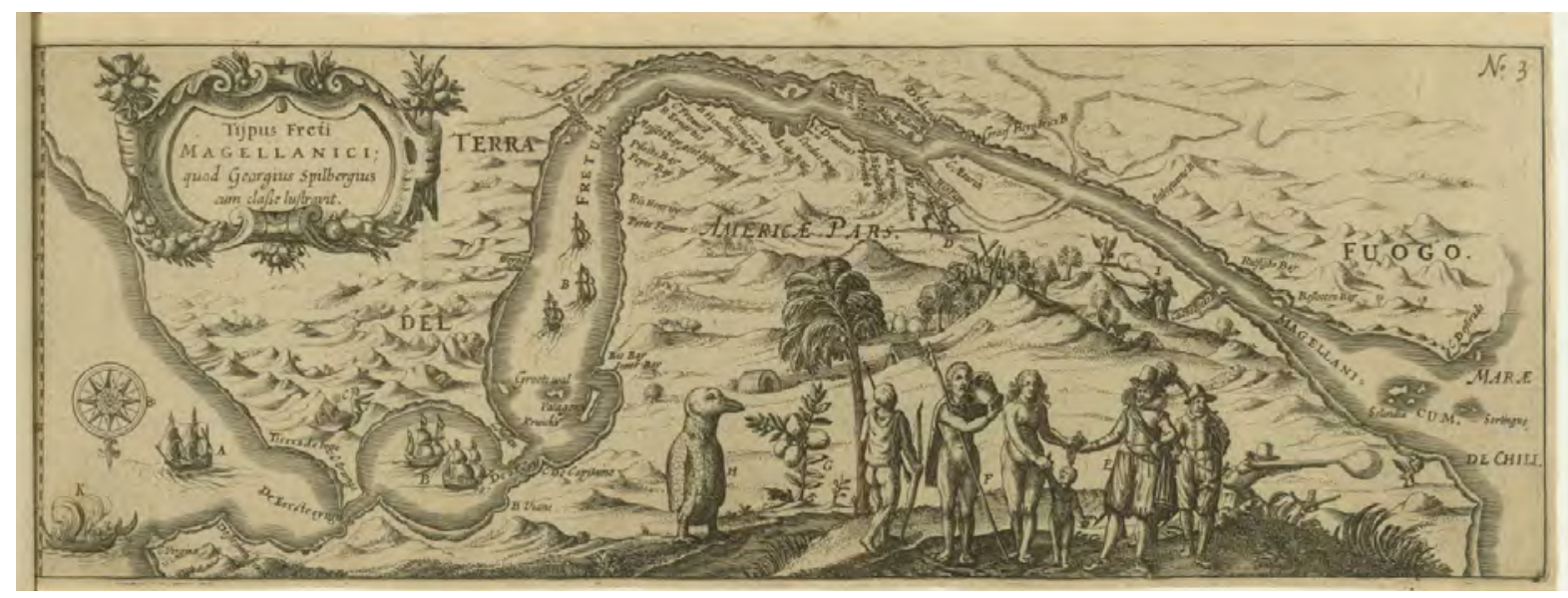

Fig. 9. Joris van Spilbergen (1619). Tijpus Freti Magellanici quod Giorgius Spilbergius cum classe lustravit. Leiden: Nicolaes van Geelkercken. John Carter Brown Library.

las figuras hechas por Hans Weigel para ilustrar al "brasileño de América" en su libro de trajes del mundo, publicado en la ciudad de Nüremberg en $1577^{74}$. Ahora bien, al igual que con la figura del hombre de falda y tocado de plumas, resulta de interés señalar su perdurabilidad en el repertorio iconográfico del área magallánico-fueguina, que se constata una vez más en los mapas de Hulsius, Visscher y Guillermo Blaeu ${ }^{75}$. El hecho de que se destaquen sus pechos caídos y el uso de una capa como única vestimenta se vincula directamente a las descripciones dadas por los viajeros holandeses, aunque también Pigafetta (1971) había resaltado que sus tetas, colgantes, tienen más de un pie de longitud ${ }^{76}$. Según el relato de De Weert, la mujer encontrada en la isla Magdalena era:

mediana en la constitución de sus miembros y tenía un vientre prominente que le colgaba, cuerpo rosáceo, gestos salvajes y altaneros y cabellos negros, los cuales suelen cortar por detrás con conchillas, a falta de cuchillos... Llevaba a manera de adorno conchillas suspendidas del cuello y cubierta la espalda por una piel hirsuta [...] El resto de su cuerpo

74 Se trata del Habitus praecipuorum populorum tam virorum quam foeminarum singulari arte depicti..., publicado en la ciudad de Nüremberg en 1577.

75 El mapa de Blaeu aquí referido es el Americae nova tabula de 1655. En el margen inferior derecho aparece representada una pareja de habitantes del Estrecho junto a estaba desnudo; sus mamas pendian a manera de ubres de vaca; su boca era grande y torcida; sus piernas, torcidas; sus tobillos, abiertos ${ }^{77}$.

Completan el repertorio iconográfico sobre el área magallánico-fueguina las figuras de un pingüino y de un molusco, asociados a la región del Estrecho a partir del relato inglés sobre los recursos alimenticios disponibles en la zona y la caza indiscriminada de pingüinos realizada por ingleses y holandeses con el objetivo de aprovisionarse para la continuación del viaje. Más allá de la hambruna padecida por los pobladores de la Ciudad del Rey Don Felipe, la cantidad de marisco apto para el consumo parece ser reconocida por españoles e ingleses como un recurso alimenticio en disponibilidad ante posibles carestías. Así, por ejemplo, a poco de establecida la colonia fundada por Sarmiento de Gamboa, la Sumaria relación hace hincapié en las bondades de la fauna local: Y la gente se sustentaba muy bien con marisco y lobos marinos y algunos pescadillos. Hay mucha sardina y pescado cecial, muchas avestruces y gallinas de papada. Hacíase provisión de pescado fresco para el invierno ${ }^{78}$. Los ingleses y

un niño.

76 Pigafetta, 1971, op. cit., p. 25.

77 De Weert y Schouten, 2010, op. cit., p. 104.

78 Sarmiento de Gamboa, 2015. Sumaria relación. Estudio y edición de Joaquín Zuleta Carrandi. Editorial Iberoamericana-Veruvuert, Madrid, p. 231. 
Fig. 10. "A Secotan priest" en Thomas Hariot (1590). Admiranda narratio fida tamen de commodis et incolarum ritibus Virginiae....

Frankfurt: Theodore De Bry. John Carter Brown Library.

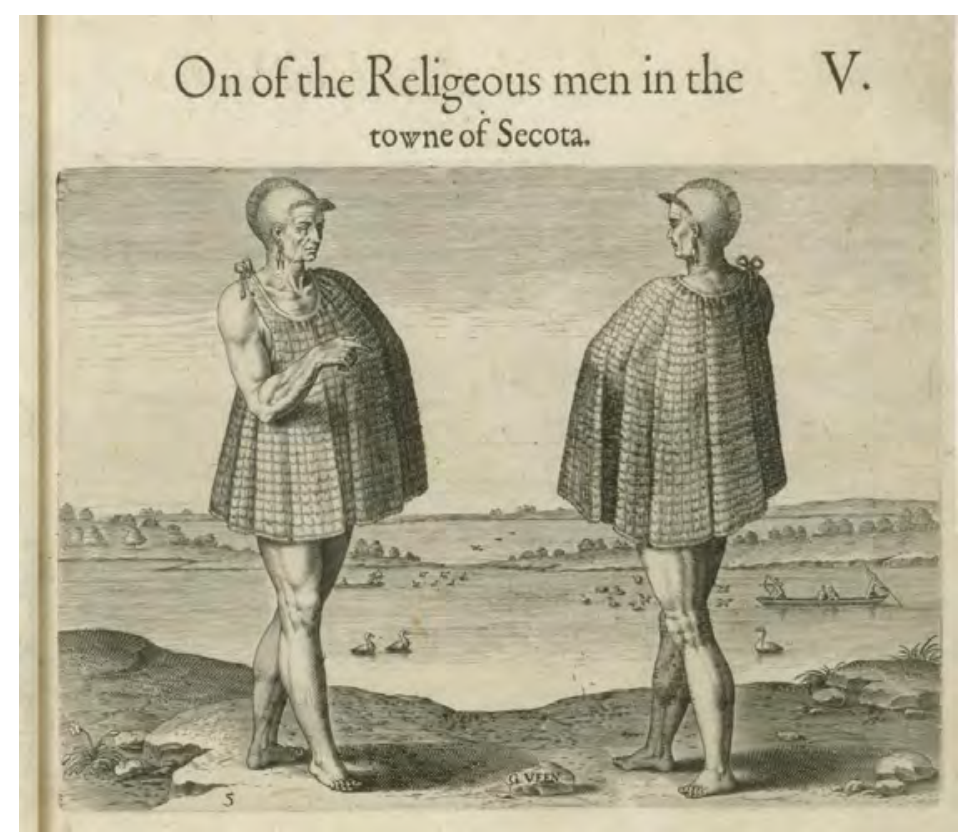

holandeses tampoco desestimaron la presencia de pingüinos, que cazaron en cantidades en las islas Magdalena y Marta, así como en zonas aledañas.

Junto al auge de la cartografía holandesa, los cuatro personajes, acompañados alternativamente de la fauna vinculada a la región, devinieron un conjunto representativo del área patagónica. En este sentido, así como Michiel van Groesen ha sostenido para las compilaciones de los De $\mathrm{Bry}^{79}$, es posible afirmar que la combinación de imágenes existentes y nuevos grabados confluyó en la conformación de nuevas secuencias iconográficas, que a su vez configuraron el modo en que los lectores observaron desde la distancia el mundo ultramarino. Ciertamente, más allá de que fuesen representadas en su totalidad o en partes, las figuras hasta aquí analizadas devinieron una forma de identificar aquel espacio geográfico en los mapas holandeses (y aun en la cartografía europea en general) del período subsiguiente.

\section{LA "TIERRA DE GIGANTES" COMO ESPACIO CARTOGRÁFICO ICÓNICO: ALGUNAS REFLEXIONES FINALES}

Han sido esbozados hasta aquí algunos de los circuitos hechos por las imágenes que, a comienzos del siglo XVII, fueron asociadas inequívocamente al área magallánico-fueguina. En principio, fueron las Provincias Unidas de los Países Bajos las que difundieron sus experiencias de navegación en la búsqueda de una posible ruta por los mares del sur hacia las Molucas. Sus relatos de viaje fueron hábilmente traducidos en imágenes cartográficas de amplia circulación que, apropiándose de elementos en ocasiones ideados para otros espacios y contextos, terminaron por dar cuenta de los recursos, usos y costumbres de las poblaciones patagónico-fueguinas. Los personajes surgidos de este proceso de transposición fueron el producto de la acción conjunta de los editores (i.e. Hulsius, Claesz), grabadores y cartógrafos (i.e. Keere, Visscher, Blaeu, etc.) holandeses, quienes realizaron una sintesis iconográfica de un espacio estratégico a escala mundial.

En otras palabras, en el período de mayor rivalidad con la monarquía ibérica, la experiencia holandesa fue interpretada, ilustrada y traducida en imágenes cartográficas que, con mayores o menores adaptaciones, se volvieron representativas de un área cuya importancia geopolítica era reconocida por toda Europa. El valor del Estrecho tanto para el comercio con Oriente cuanto para el saqueo de los puertos españoles sobre el Pacífico americano 
ya había sido advertido por los ingleses, cuyas actividades corsarias en América meridional en el contexto de sus viajes de circunnavegación habían alertado a la corona española y fundamentado, en consecuencia, las expediciones al área magallánicofueguina enviadas desde Perú. Tal como Richard Hakluyt había señalado en su panfleto titulado $A$ Discourse of the Commodity of the Taking of the Straight of Magellanus (1579), el estrecho de Magallanes era la puerta de entrada al tesoro tanto de las Indias Orientales como de las Occidentales $^{80}$.

En este contexto político, la producción y circulación del repertorio iconográfico aquí estudiado invita a reflexionar sobre las posibles motivaciones y finalidades detrás de tal selección de imágenes. Al respecto, debe señalarse que las escenas y personajes asociados al Gigantum Regio están directamente vinculados a la experiencia holandesa en la zona. Desde la firma del Tratado de Utrecht en 1579, el impulso comercial y posicionamiento global de las Provincias Unidas por sobre sus competidores se reflejó en el protagonismo que sus relatos tuvieron dentro de la saga de viajes y compilaciones existentes. Al igual que Inglaterra, a partir de su despegue comercial a fines del siglo XVI, las Provincias Unidas también merodearon las costas del Atlántico y el Pacífico austral en busca de un pasaje que pudiera garantizar un comercio más fluido con Oriente. Sus viajes exploratorios, que preocuparon una vez más a la corona ibérica, dieron lugar a una singular forma de imaginar la región patagónica, que acompañó los relatos que se publicaron a la par y cuyas imágenes pervivieron en distintos formatos y soportes hasta fines del siglo XVIII.

En efecto, los grabados de los habitantes de aquellas regiones australes fueron reutilizados

80 Taylor, 1935. The Original Writings and Correspondence of the two Richard Hakluyts. The Hakluyt Society, Londres, p. 139.

81 Martínez, 2015. Usos del pasado y confiabilidad de las fuentes: Antoine-Joseph Pernety y la disputa sobre la naturaleza de América en el siglo XVIII. Corpus [En línea], 5(2), recuperado de http://journals.openedition.org/ corpusarchivos/1449

82 Véase el mapa de pared elaborado por Pieter Goos en Ámsterdam hacia 1680 que lleva por título West-Indische Paskaert waer in de graden der breedde over weder zyden vande middelyn wassende so vergrooten dat die para defender la superioridad del territorio americano en nuevos contextos políticos tales como el debate sobre la naturaleza de América ocurrido hacia $1770^{81}$. A su vez, algunas imágenes en particular parecen haberse dislocado de sus contextos originales de producción para volverse representativas de América meridional en su totalidad y no ya del área magallánico-fueguina específicamente. Tal es el caso de la figura de la mujer alimentando a su niño con un ave, cuyas apariciones son recurrentes en las cartelas de los mapas holandeses sobre las Indias Occidentales ${ }^{82}$ y en aquellos mapas destinados a representar la totalidad del continente americano elaborados en la segunda mitad del siglo XVII, entre los que se destacan las versiones de la Novissima et accuratissima totius Americæ descriptio realizadas por Nicolaes Visscher y Frederik de Wit en 1682 y 1688 respectivamente ${ }^{83}$. Sin duda, uno de los casos más llamativos de esta dislocación espacio-temporal es la aparición de esta figura en el mapa de El gran río Marañón, o Amazonas, con la misión de la Compañía de Jesús (1707) (Fig. 11), realizado por el padre jesuita Samuel Fritz en Quito tras recorrer el cauce del Amazonas. $\mathrm{Su}$ cartela presenta en un primer plano a la mujer, ahora sentada, alimentando a su niño con la carne de un ave. A su lado, la imagen de un indígena convertido al catolicismo (pues lleva una cruz colgada en su pecho) pareciera dar prueba del éxito de la misión. Al igual que en los otros casos referidos, la escena del viaje de De Weert reaparece así en un nuevo contexto, cargada de sentidos que solo pueden leerse en diálogo con el mapa y las imágenes que contiene.

Ahora bien, más allá de los usos posteriores o de la independencia que estos motivos iconográficos adquirieron de sus contextos

geproportioneert syn tegen hunne nevenstaende graden de lengde.

83 Véase la Novissima et accuratissima totius Americæ descriptio (1682), de Nicolaes Visscher II, basada en su creación de 1660, y la Novissima et accuratissima totius Americæ descriptio de Frederik de Wit, confeccionada en Ámsterdam c. 1688 en base al ejemplar de c. 1672. En ambos casos, la mujer que alimenta al niño con un ave se encuentra inserta en una escena en la que distintos personajes sostienen accesorios representativos del continente americano o realizan acciones asociadas a dicho territorio desde los primeros viajes exploratorios. 


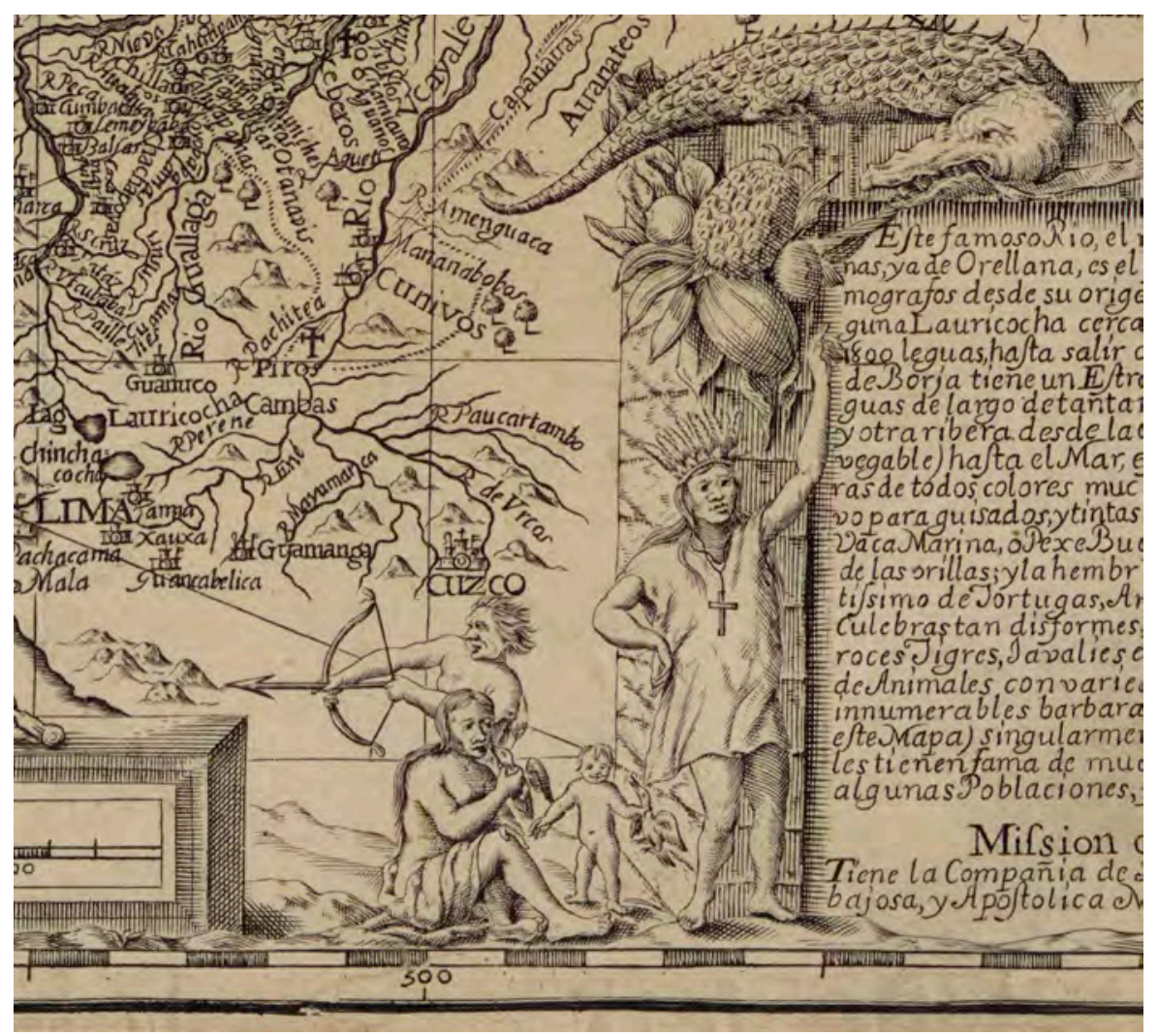

Fig. 11. Samuel Fritz (1707). El gran rio Marañon, o Amazonas, con la mission de la Compañia de Jesus geograficamente delineado por el P. Samuel Fritz, missionero continuo en este rio. P. J. de N. Societatis Jesu, quondan in hoc Maranone missionarius, sculpebat. 10 leguas castellanas. Quito: [s.n.] Detalle. Biblioteca Nacional de Francia.

originales de producción, vale recordar que la legitimidad de tales imágenes se sustentó, en un principio, en la mirada del viajero que, en condición de testigo, había visto con sus propios ojos lo que narraba. Las experiencias sobre el terreno de navegantes holandeses tales como van Noort, de Weert, Schouten y Spilbergen proporcionaron, en este sentido, las primeras impresiones sobre las que se fundamentó la síntesis iconográfica patagónicofueguina. Sobre este último punto, llama la atención, sin embargo, el marcado contraste entre la iconografía sobre el Estrecho y las penurias descriptas por los viajeros. En efecto, las imágenes de hombres de gran tamaño, mujeres y niños en la región patagónica son casi antagónicas frente a la visión dada por los viajeros españoles sobre la carestía y condiciones inhóspitas del clima en la

84 Tal como señala María Jesús Benites, la carta de Transilvano hace ingresar a las costas patagónicas en la escritura como región ${ }^{84}$, e incluso frente a las penurias narradas por los holandeses cuyas travesías fracasaron por falta de alimentos o condiciones climáticas severas. De tal forma, los pingüinos, moluscos, tocados y faldas de plumas, además de la robustez de los cuerpos, parecieran ocultar las dificultades y obstáculos naturales propios del cruce por aquellas aguas.

Ahora bien, la presencia de hombres y mujeres robustos en los mapas y relatos sobre el Estrecho también podría considerarse una "prueba" de que la vida en aquellas latitudes era posible. Este último punto bien podría vincularse a la finalidad o intención detrás de la elección de tales imágenes, pues tanto la iconografía como la simpleza con la que es dibujado el pasaje interoceánico parecieran invitar a futuras navegaciones. En efecto, las

un espacio hostil e intimidante, generador de violencia y enfrentamientos. Benites, 2013, op. cit., p. 200. 
familias ("salvajes" pero bien formadas) presentes en los mapas de la región se sitúan en una traza relativamente limpia del Estrecho. A la disposición de los personajes se suma la ausencia de cualquier marca o referencia al hecho de que la zona se encuentra nominalmente bajo dominio español ${ }^{85}$. Todos estos elementos parecieran propiciar la navegación por el pasaje interoceánico que, en contraste con las descripciones de los viajeros y la cantidad concreta de navegaciones realizadas, no pareciera presentar grandes dificultades. En un período de fuerte competencia inter-imperial, tal como la representó la cartografía holandesa, la "Tierra de los Gigantes" aparece como un espacio habitado y por ello habitable, argumento capital para todo aquel que se atreviera a navegar por debajo de los 40 grados de latitud Sur.

\section{BIBLIOGRAFÍA}

Amman, J., \& Weigel, H. (1577). Habitus praecipuorum populorum tam virorum quam foeminarum singulari arte depicti. Nüremberg: Hans Weigel.

Aucardo Chicangana, Y. (2005). El festín antropofágico de los indios tupinambá en los grabados de Theodore De Bry, 1592. Fronteras de la Historia, 10, 19-82.

Benites, M. J. (2013). 'La mucha destemplanza de la tierra': una aproximación al relato de Maximiliano de Transilvano sobre el descubrimiento del estrecho de Magallanes. Orbis Tertius, XVII(19), 200-207.

Castro, X., Hamon, J., \& Thomaz, L. F. (Eds.) (2007). Le voyage de Magellan (1519-1522). La relation d'Antonio Pigafetta \& autres témoignages. Prefacio de Carmen Bernand y Xavier de Castro. Paris: Chandeigne.

Cerezo Martínez, R. (1994). La cartografía náutica española en los siglos XIV, XV y XVI. Madrid: Consejo Superior de Investigaciones Científicas.

Córdova-Bello, E. (1965). Compañias holandesas de navegación: Agentes de la colonización neerlandesa. Sevilla: Escuela de Estudios Hispanoamericanos.

Davies, S. (2016). Renaissance Ethnography and the Invention of the Human: New Worlds, Maps, and Monsters. Cambridge: Cambridge University Press.

De Weert, S., \& Schouten, W. (2010). Descubrimiento del Cabo de Hornos. Relación histórica de dos navegaciones holandesas. Buenos Aires: EudebaColección Reservada del Museo del Fin del Mundo.

Drake, F. (1652). The World Encompassed by Sir Francis
Drake, collected out of the Notes of Master Francis Fletcher. Londres: Nicholas Bourne.

Duvernay-Bolens, J. (1988). Les Géants Patagons ou l'espace retrouvé: Les débuts de la cartographie américaniste. L'Homme, 28(106/107), 156-173.

Duvernay-Bolens, J. (1995). Les Géants patagons: voyage aux origines de l'homme. Paris: Éditions Michalon.

Duviols, J. P. (1985). L'Amérique vue et rêvée. Paris: Promodis.

Ginzburg, C. (2010). El hilo y las huellas. Buenos Aires: Fondo de Cultura Económica.

Herrero, M. (1999). Las Provincias Unidas y la Monarquía Hispánica: (1588-1702). Madrid: Cuadernos de Historia 72 y Arco Libros.

Israel, J. I. (1997a). Conflicts of Empires: Spain, the Low Countries and the struggle for world supremacy, 1585-1713. Londres: The Hambledon Press.

Israel, J. I. (1997b). La República holandesa y el mundo hispánico: 1606-1661. Madrid: Nerea.

Israel, J. I. (1998). The Dutch Republic: Its Rise, Greatness and Fall, 1477-1806. Nueva York: Clarendon Press of Oxford University Press.

Jacob, C. (1992). L'empire des cartes: approche théorique de la cartographie à travers l'histoire. Paris: A. Michel.

Jacob, C. (1996). Toward a Cultural History of Cartography. Imago Mundi, 48, 191-198.

Lestringant, F. (2003). Sous la leçon des vents. Le monde d'André Thevet, cosmographe de la Renaissance. Paris: Presses de l'Université Paris-Sorbonne.

Lestringant, F. (2012). Les Patagons de la carte (1520-1620). En C. Barthe \& P. Mason (Dirs.), Patagonie. Images du bout du monde. Paris y Arles: Musée du quai BranlyActes Sud, 12-27.

Lida de Malkiel, M. R. (1952). Para la toponimia argentina: Patagonia. Hispanic Review, 20(4), 321-323.

Lois, C. (2015). Quinta pars o terrae incognitae? La cuestión de la verosimilitud en la representación cartográfica de lo desconocido. Terra Brasilis, 4, 1-19.

Martínez, C. (2015). Usos del pasado y confiabilidad de las fuentes: Antoine-Joseph Pernety y la disputa sobre la naturaleza de América en el siglo XVIII. Corpus, 5(2), 1-35.

Martinic, M. (1971). Reseña del descubrimiento y de la evolución cartográfica de la región magallánica. Punta Arenas: Instituto de la Patagonia.

Martinic, M. (2004). Archipiélago patagónico. La última frontera. Punta Arenas: Ediciones de la Universidad de Magallanes.

Martinic, M. (2012). Los holandeses en las islas de los Pingüinos

85 En el mapa de Hulsius la ciudad de Philippopolis aparece incluso rebautizada. 
(1599-1615). Magallania, 40(2), 7-22.

Pagden, A. (1993). European Encounters with the New World. New Haven y Londres: Yale University Press.

Portuondo, M. (2009). Secret Science: Spanish Cosmography and the New World. Chicago: University of Chicago Press.

Ratto, H. (1930). Actividades maritimas en la Patagonia durante los siglos XVII y XVIII. Buenos Aires: Guillermo Kraft.

Schilder, G. (1986-2013). Monumenta Cartographica Neerlandica, 9 vols. Alphen aan den Rijn: Uitgeverij Canaletto.

Schilder, G. (2017). Early Dutch Maritime Cartography: the North Holland School of Cartography (c.1580-c.1620). Leiden: Brill, Hes \& De Graaf.

Taylor, E. G. R. (1935). The Original Writings and Correspondence of the two Richard Hakluyts. Londres: The Hakluyt Society.

Urbina, X. (2013). Expediciones a las costas de la Patagonia Occidental en el período colonial. Magallania, 41(2), 51-84.

Usher, P. J. (2014). 'Ils n'ont point de ville': l'urbanisation des espaces lointains a la Renaissance. Seizième Siècle, 10, 227-244.

Van Groesen, M. (2005). Barent Jansz. en de familie De Bry. Twee visies op de eerste Hollandse expeditie 'om de West' rond 1600. De zeventiende eeuw, 21(1), 29-48.

Van Groesen, M. (2012). The Representations of the Overseas World in the De Bry Collection of Voyages (15901634). Leiden-Boston: Brill.

Wagner, H. R. (1951). A Map of Sancho Gutiérrez of 1551. Imago Mundi, 8(1), 47-49.

Zandvliet, K. (2007). Mapping the Dutch World Overseas in the Seventeenth Century. En D. Woodward (Ed.), The History of Cartography, Volume Three, Part 2 (pp. 1433-1462). Chicago: Chicago University Press.

\section{FUENTES}

Fritz, S. (1707). El gran rio Marañon, o Amazonas, con la mission de la Compañia de Jesus geograficamente delineado por el P. Samuel Fritz, missionero continuo en este rio. P. J. de N. Societatis Jesu, quondan in hoc Maranone missionarius, sculpebat. 10 leguas castellanas. Quito: [s.n.]

Goos, P. (c. 1680). West-Indische Paskaert waer in de graden der breedde over weder zyden vande middelyn wassende so vergrooten dat die geproportioneert syn tegen hunne nevenstaende graden de lengde.
Ámsterdam: Johannes Van Keulen. Barry Lawrence Ruderman. Mapa de pared, 39x32 pulgadas.

Gutiérrez, S. (1551). Carta Mapamundi. Biblioteca Nacional de Viena. Dibujo coloreado a mano sobre pergamino. 4 hojas, tamaño total $336 \times 108 \mathrm{cms}$.

Hakluyt, R. (1589). Principall Navigations, Voiages and Discoveries of the English Nation, Made by Sea or over Land, to the most remote and farthest distant Quarters of the earth at any time within the compasse of these 1500 yeeres. Londres: Bishop y Newberie.

Hulsius, L. (1626 [1602]). Delineatio Freti Magellanici. Frankfurt: Hartmanno Palthenio.

Linschoten, J. H. (1596). Delineatio ómnium orarum totius Australis partis Americae, Dictae Peruvianae, a $R$ de la Plata, Brasiliam..., grabado en metal por Arnold Florent van Langren. Ámsterdam: Cornelis Claesz.

Martines, J. (1587). Typus Orbis Terrarum. Messina. Biblioteca Nacional de España. Manuscrito coloreado a mano sobre pergamino, tamaño total $58,5 \times 81 \mathrm{cms}$.

Mercator, M. (1595). America sive India nova ad magnae Gerardi Mercatoris aui universalis imitationem in compendium redacta. Per Michaelem Mercatorem Duysburgensem, publicado en el Atlas cosmographicae meditationes de fabrica mundi. Ámsterdam: [s.n.]

Pernety, A. J. (1770). Histoire d'un voyage aux Isles Malouines, fait en 1763 \& 1764; avec des observations sur le détroit de Magellan, et sur les Patagons, Par Dom Pernetty, Abbé de l'Abbaye de Burgel, Membre de l'Académie Royale des Sciences \& Belles Lettres de Prusse; Associé Correspondant de celle de Florence, \& Bibliothécaire de Sa Majesté le Roi de Prusse. Paris: Saillant et Nyon, Delalain.

Pigafetta, A. (1526). Le Voyage et navigation faict par les Espaignolz és Isles de Mollucques [Texte imprimé], des iles qu'ilz ont trouvé audict voyage, des roys d'icelles, de leur gouvernement et manière de viure, avec plusieurs aultres choses... Paris: Simon Colines.

Pigafetta, A. (1971). Primer viaje en torno del globo. Buenos Aires: Centro Editor de América Latina.

Potgieter, B. J. (1600). Wijdtloopigh verhael van tgende de vijf schepen. Ámsterdam: [s.n.]

Ramusio, G. B. (1550), Primo volumen delle navigationi et viaggi. Venecia: Heredi di Lucantonio Giunti.

Santa Cruz, A. (c. 1540). Islario general de todas las islas del mundo. Biblioteca Nacional de España. Manuscrito de 111 mapas coloreados a la aguada, tamaño total $28 \times 21 \mathrm{cms}$

Sarmiento de Gamboa, P. (2005). Viaje al estrecho de 
Magallanes y noticia de la expedición que después hizo para poblarlo. Estudio preliminar de José Luis Lanata; artículos anexos y notas de Rubén A. Arribas. Buenos Aires: Eudeba.

Sarmiento de Gamboa, P. (2015). Sumaria relación. Estudio y edición de Joaquín Zuleta Carrandi. Madrid: Editorial Iberoamericana-Veruvuert.

Spilbergen, J. (1619). Tijpus Freti Magellanici quod Giorgius Spilbergius cum classe lustravit. Leiden: Nicolaes van Geelkercken.

Thevet, André (1575). La Cosmographie Universelle d'André Thevet cosmographie du Roy. París: Guillaume Chaudiere.

Transilvano, M. (2018). Carta escrita por Maximiliano Transilvano de cómo y por qué y en qué tiempo fueron descubiertas y halladas las islas Molucas, donde es el propio nacimiento de la especiería, las cuales caen en la conquista y marcación de la corona real de España. Y divídese esta relación en veinte párrafos principales. AA.VV. La primera vuelta al mundo. Madrid: Miraguano-Polifemo Ediciones, pp. 13-56.

Visscher, N. (1633). Americae nova descriptio. Ámsterdam: Abraham Goos (mapa basado en el original de Pieter van den Keere, realizado en 1614).

Visscher, N. (c. 1682). Novissima et accuratissima totius Americæ descriptio. Ámsterdam: [s.n.]

Viuda e hijos de Theodore De Bry (1602). Americae nona et postrema pars, qua de ratione elementorum, de novi orbis natura, de hujus incolarum... Frankfürt: Matthäus Becker.

Wit, F. de (c. 1688). Novissima et accuratissima totius Americæ descriptio. Ámsterdam: [s.n.] 